\title{
GENDER AND LAND DEGRADATION NEUTRALITY: A CROSS-COUNTRY ANALYSIS TO SUPPORT MORE EQUITABLE PRACTICES
}

Short title: GENDER AND LAND DEGRADATION NEUTRALITY

Key words: Sustainable land management, gender equality, SDGs, female empowerment, land rights, women

Uche T. Okpara ${ }^{1}$, Lindsay C. Stringer ${ }^{1}$, Mariam Akhtar-Schuster ${ }^{2}$

${ }^{1}$ Sustainability Research Institute, School of Earth and Environment, University of Leeds, Woodhouse Lane Leeds, LS2 9JT, UK

2 Secretariat DesertNet International, Biocentre Klein Flottbek and Botanical Garden, University of Hamburg, Ohnhorststr. 18, D-22609 Hamburg, Germany

Correspondence: Uche Okpara - now affiliated to the Natural Resources Institute, School of Engineering and Science, University of Greenwich, UK (E: u.t.okpara@gre.ac.uk; T: +44 7440495212) 


\begin{abstract}
Women and men have unequal opportunities to address land degradation. While adoption of Sustainable Development Goal target 15.3 leads the world to 'strive towards land degradation neutrality (LDN)' by 2030, gender concerns are sparsely considered in LDN programming to date. To achieve LDN in regions with deeply entrenched socio-cultural norms requires genderresponsiveness, accounting for the varied gender components of land degradation. This paper identifies innovative entry points for, and benefits of, integrating gender issues into LDN, as well as the risks of gender inaction. Assessment of the literature on the links between gender and land reveals land degradation is gendered and closely tied to gender biases in land rights, access to resources and incentives, opportunities to participate in decision-making, and the distribution of costs/benefits of projects targeting land improvement. Analysis of selected LDNrelated projects shows that interventions seem to target gender biases by engaging: women's groups that are locally-recognised as change agents in driving inclusiveness; and gender specialists to coordinate gender mainstreaming activities. Entry points for gender-responsive LDN are identified, including interventions that: merge LDN gender plans with existing gender schemes at local and global levels; enable gender-sensitive early warning systems; and narrow gender disparities and safeguard women's land rights through gender-sensitive LDN financing mechanisms. Gender-responsive LDN is one of several avenues to support growing international efforts to promote gender equality and female empowerment, alongside movement towards a future where more balanced relations ensure women and men can interact with and care for land in more equitable and non-hierarchical ways.
\end{abstract}

KEY WORDS: sustainable land management, gender equality, SDGs, female empowerment, land rights, women

\title{
INTRODUCTION
}

Links between gender equality, female empowerment and sustainable land management (SLM) are long recognised, but have attracted growing academic and policy interest more recently (Kondylis et al., 2016; Doss et al., 2018). This has been largely driven by the persistence of gender barriers in achieving development, and was boosted by the Sustainable Development Goals (SDGs) which spur action to preserve 'life on land' (Goal 15) and promote gender equality (Goal 5). Making progress towards these goals is fundamental for achieving other SDGs and their targets (see the IPBES Report, 2018). Action to preserve 'life on land' requires tackling land degradation since approximately 12 million hectares of land are degraded annually, undermining the wellbeing of 3.2 billion people in more than 169 countries worldwide (Stringer et al., 2017; UNCCD, 2017). Land degradation has a strong gender component, yet statistics on land degradation mask the gendered nature of degradation, in particular, the different roles women and men play in land degradation. Researchers and practitioners have argued that degradation threats can be reduced if gender gaps in land rights, access to finance and credit, and participation in actions to avoid, reduce and reverse degradation, and knowledge dissemination, were closed (UNCCD, 2017). As the world strives towards land degradation neutrality (LDN), gender-responsive actions that contribute to LDN, and that recognise women and men as equally important and legitimate stakeholders, are therefore vital.

LDN links SLM, land restoration and land rehabilitation practices. It is addressed in target 15.3 of the SDGs and provides a key political opportunity to stabilise or increase the amount and quality of land resources globally by 2030 (Sietz et al., 2017). The United Nations Convention to Combat Desertification (UNCCD) recognises gender equality, female empowerment and land rights as essential for successful LDN outcomes, with Orr et al. (2017) calling for LDN actions that: include gender analysis as a way to account for women's participation/contribution in LDN decision-making; and enable LDN assessment based on gender-sensitive indicators that capture sex-disaggregated data as a way to enable accurate 
monitoring of progress. Integrating gender considerations into LDN is desirable from a human rights and social justice/equity perspective. This can help uncover and address underlying structural inequalities and power imbalances between women and men, facilitating LDN outcomes that deliver ecological and economic benefits more equitably to both women and men.

Although a strategic gender-responsive and socially-inclusive approach can foster a balanced representation of men and women in sustainable development initiatives, LDN's gender dimensions and priority to include and empower women and men equally (e.g. by giving them a voice in decisions that critically affect their wellbeing) remain unclear. Unlocking the potential of a gender-equitable ${ }^{1}$ LDN rests critically on the aspirations and support of those who depend on land-based livelihoods - whose rights and access to land must be protected and promoted for LDN-facing initiatives to be sustainable. Similarly, movement towards LDN in any country would depend on the cooperation and commitment of numerous actors and user communities/stakeholders at all levels. LDN is, and will be, pursued and implemented in countries (and contexts) characterised by histories of land tenure conflicts, ineffective land governance systems, and where patriarchal norms discriminate against women and girls. Yet, limited strategic guidelines exist to support countries on the scope of gender-equitable LDN actions to ensure that initiatives do not perpetuate historical inequalities and injustices and/or marginalise indigenous and local communities. Patriarchal structures in places where LDN related projects are ongoing necessitate Parties to the UNCCD to ensure that such projects are informed by human rights guidelines and/or global gender norms to achieve both gender equality and land resilience. Advancing gender-equitable LDN actions at a time when there is renewed global commitment to empower women (and girls) offers a window of opportunity to tackle structural and procedural constraints that undermine women's effectiveness as agents of change in land management.

This article identifies some of the ways countries can more systematically and consistently integrate gender equality into LDN to better incentivise women's participation and leadership capacity, and as such, support more equitable practices. It assesses the literature on the links between gender and land (see Appendix S1) to understand how gender and women's rights are conceived and addressed in agricultural and land-based livelihood systems where land degradation is stark. It critically analyses ongoing and past projects that contribute to measures to avoid, reduce and reverse land degradation around the world to understand how gender and women's issues are considered. In doing so, it uncovers innovative entry points for, and identifies the benefits of, integrating gender issues into LDN, as well as identifying the risks of not doing so. The article stimulates both scholarly and policy-oriented thinking on pathways towards more equitable, gender-balanced LDN actions, and a future where women and men can interact with and care for land resources in more equal and non-hierarchical ways.

\section{RESEARCH DESIGN AND METHODOLOGY}

We undertook a desk-based document search and literature review supported by evaluation of evidence from LDN-related projects from around the world. Our literature review (synthesised in Appendix S1) indicates that perceptions of gender and land are deeply rooted in cultures, vary widely within and between societies, and are dynamic. Gender relates to socially constructed differences between women and men on the basis of their roles, responsibilities, behaviours, daily activities and attributes. Eco-feminists conceive the links between land use, ownership and management as substantially mediated through gender, focusing in particular on women as victims of land degradation (Doss et al., 2015; Hirao, 2016). Our review demonstrates that gender bias exists in: land rights; agricultural/domestic labour

\footnotetext{
1 The terms gender-sensitive, gender-responsive and gender-equitable are used interchangeably to mean: 'recognition of gender issues in relation to socially constructed differences in the roles, responsibilities, opportunities and realities of women and men; and treatment of women and men as equal humans'.
} 
divisions; access to resources and incentives; participation in decision-making opportunities; and sharing of costs/benefits of intervention projects. Such bias can fuel inequalities and social injustices; and can be tied to the ways women and men degrade the land (FAO, 2009; Meinzen-Dick et al., 2017). The notion of inequality in the theory and practice of land management and restoration/rehabilitation does not suggest that women and men are unequal humans, but rather that their roles, responsibilities, opportunities and realities are dependent on whether they are born female or male (FAO, 2018).

While awareness of gender dimensions related to land has risen significantly, current LDN literature is scarce concerning: i) how LDN actions can help address/overcome gender disparities alongside its primary goals to avoid, reduce and reverse land degradation; ii) the advantage(s) of bringing gender into mainstream LDN processes; and iii) the risks we face by not doing so. Implementing, achieving and maintaining LDN, e.g. in places with deeply entrenched patriarchal norms, underscore the need for a better understanding of these issues.

We identified and evaluated a sample of projects that contribute to measures to avoid, reduce and/or reverse land degradation (i.e. LDN-related projects) (see Table 1 for the criteria used to include projects). We adopted the guidelines of Waddington et al. (2012) which specify a replicable protocol for searching defined project databases, selecting evidence against predefined criteria and reviewing/synthesising the selected evidence. Evaluation sought to elucidate evidence of concrete actions (planned or implemented) to: bring about gender equality in land rights and workloads; facilitate equality in knowledge sharing and transfer; and promote participatory decision-making processes in tackling land degradation, including sharing of costs/benefits from land-based initiatives. We account for the particular needs, priorities, realities and knowledge of women and men, focusing on how these are included in project planning $^{2}$ (Doss et al., 2014).

Table 1. Project inclusion and exclusion criteria.

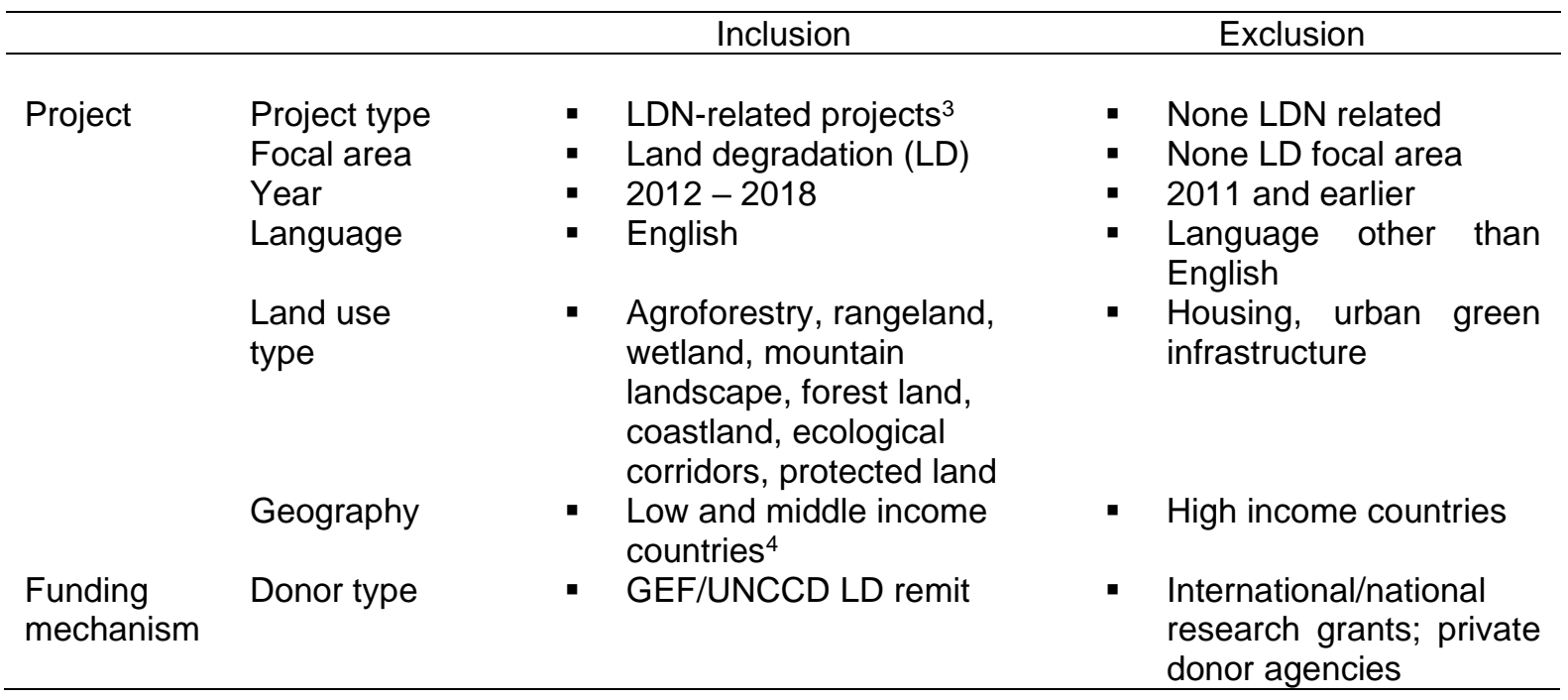

\footnotetext{
${ }^{2}$ We assessed 'planned' intervention projects (at the inception phase), rather than effectiveness/implementation outcomes of projects. This is because the majority of the LDN-related projects we included are currently ongoing.

${ }^{3}$ Owing to the scarcity of specific LDN projects aligned to the LDN Target-Setting Programme (LDN-TSP) currently implemented by the Global Mechanism of the UNCCD, we included projects that directly/indirectly contribute to measures to avoid/reduce/reverse land degradation, desertification and drought (LDDD).

${ }^{4}$ Projects included are based in Asia, Africa, South America and Eurasia - countries involved in the LDN-TSP.
} 
Our sample focused on Global Environment Facility (GEF) funded projects ${ }^{5}$ on SLM and land restoration, encompassing interventions that aim to tackle degradation, desertification and droughts (i.e. to stabilise or increase land quantity and quality), and which fall within the wider 'land degradation' focal area $(n=30)$. Selected projects (see Table $S 1$ in supplementary material) are ongoing or completed, covering the period 2012-2018. This period encompasses the time the UNCCD first voiced the idea of zero net land degradation neutrality which later evolved into LDN and SDG 15 in 2015 (Chasek et al., 2015; Stavi and Lal, 2015). Both GEF and UNCCD LDN country profile databases ${ }^{6}$ were searched to collate project documents/proposals. We do not include all LDN-related projects, but we do cover a wide range of land use types (agroforestry, rangeland, wetlands, mountain landscapes) and land degradation issues (from sustainable agriculture to large-scale rehabilitation of degraded land) across low- and middle-income countries/regions, reflecting important dimensions of gender issues considered in land-based interventions.

Project documents were examined for references to 'gender' and 'women', identifying the meanings they communicate in relation to the gendered dimensions of land degradation, and covering how women and men contribute to and are impacted by land degradation/restoration (see Table S2 for questions that guided reading and assessment of projects). Specific gender issues related to land use/ownership, safeguarding of tenure security, participatory decisionmaking and benefit sharing were then identified. This allowed us to uncover how gender matters for land degradation/restoration, whether gender relations are changing, and how women's roles are captured, to better understand the core gender issues deserving the greatest attention in pursuing LDN.

\section{PORTRAYALS OF GENDER IN LDN-RELATED PROJECTS}

Table 2 presents the typology of project core themes and associated countries in our sample. Projects, covering 34 countries, differ in the scope of gender issues/concerns covered. To tease out the central gender issues considered, we focus on two broad aspects of the gender dimensions: gendered participation and engagement; and contextual/structural gender components.

Table 2. Typology of project core theme and associated country.

\begin{tabular}{ll}
\hline \multicolumn{1}{c}{ Core theme of project } & \multicolumn{1}{c}{ Country } \\
\hline $\begin{array}{l}\text { Sustainable land management } \\
\text { (practices, systems, technologies, } \\
\text { investments) }\end{array}$ & - $\begin{array}{l}\text { Albania, Armenia, Georgia, Dominica, Ghana, } \\
\text { Jordan \& Egypt, Botswana, Chile, Madagascar, } \\
\text { Namibia, Macedonia }\end{array}$ \\
$\begin{array}{l}\text { Sustainable forest and landscape } \\
\text { management (forest landscape, } \\
\text { mountain landscape, ecological } \\
\text { corridors) }\end{array}$ & - $\begin{array}{l}\text { Chad, Brazil, Indonesia, Liberia, Sierra Leone, } \\
\text { Bosnia \& Herzegovina, Lebanon, Benin, } \\
\text { Coastal zone/water shed management } \\
\text { and ecosystem rehabilitation } \\
\text { Land degradation offset, mitigation and } \\
\text { agro-sylvo-pastoralism management } \\
\text { Protected area management }\end{array}$ \\
\end{tabular}

\footnotetext{
${ }^{5}$ We focused on GEF funded projects because GEF serves as a financial mechanism for UNCCD; it works to extend LDN projects world-wide (see https://www.thegef.org/topics/land-degradation-neutrality).

${ }^{6}$ URLs: i) https://www.thegef.org/projects?f[]=field_p_focalareas:2210; and ii) https://www.unccd.int/ actions/ldn-target-settingprogramme/ldn-country-profiles.

${ }^{7}$ Three of the projects we examined are being implemented in more than one country (see supplementary material - Table S1)
} 


\section{Gendered participation and engagement}

References to 'gendered participation' were found to be limited to mentioning women as partners alongside men in decision-making, relating to: project design/planning; validation workshops; and livelihood enhancement (Table 3). Women and women's groups partner with men because of the active role women play in agriculture, SLM, harvesting and value-addition of forest products, and community-based environmental advocacy. Partnership is also influenced by the needs to strengthen women's resilience to land degradation. One important example (demonstrating partnership) is the project on Land degradation neutrality of mountain landscapes in Lebanon where women are expected to partner (equally) with men in any dialogue initiated by the project on the basis of their role in local innovations relating to land rehabilitation, restoration and sustainability. The project accounts for the priorities of men and women - acknowledging women's vulnerability as the reason gender should be considered in addressing land degradation.

Many projects identify institutional platforms that encourage/support gendered participation. For example, the Sustainable Land Management Project in the Commonwealth of Dominica was based on the involvement of the National Council of Women in providing technical support for gender mainstreaming in SLM; the project on Promoting Sustainable Land Management (SLM) through Integrated Restoration of Ecosystems in Albania incorporates the Kolonja Women's Association to lead the development of baseline gender analysis; while the Community-based Sustainable Dryland Forest Management Project in Gambia employs the expertise of the Agency for the Development of Women and Children to coordinate participatory gender-based activities in forest conservation. In these countries, project interventions seem to target gender bias by engaging women's groups that are locally recognised as change agents in driving inclusiveness.

Table 3. Central gender issues recognised based on 'gendered participation'.

Evidence of participatory aspects of the gender dimension identified

- Participation of women's groups in developing baseline gender analysis

- Stakeholder consultation integrating women and men equally - to identify needs and priorities

- Decision-making covering: training/capacity building, land use planning, awareness raising, outreaches, business planning

- Partnership for enabling gender equality promoted by: accounting for socioecological needs in project locations; engaging several agencies (NGOs, CBOs, extension services) to strengthen the voice of women; using women and men representatives in project planning

Several other projects (e.g. Mainstreaming SLM in rangeland areas in Botswana; Sustainable forest and landscape management in Bosnia and Herzegovina; and Integrated communitybased forest and catchment management through an ecosystem service approach in Thailand) highlight the role of community-based groups (such as Women's Self-Help Groups) in setting up social mobilisation activities and coordination of rural women's representation in environmental advocacy. 'Mainstreaming biodiversity into the management of the coastal zone in the Republic of Mauritius' provides a good example of a gender-sensitive participatory approach in project planning. By combining a gender lens and a Human Rights-Based Approach, the project aims to reduce the gender bias which assumes that men are the sole breadwinner and household head, and the chief recipients of household income. The project distinguishes women and men as household beneficiaries of project outcomes, ensuring that: i) women's participation is not hampered by unpaid care work; ii) alternative care arrangements are considered as part of development of sustainable and alternative livelihoods; iii) women's participation does not worsen their unpaid work load; and iv) the project does not take advantage of gender bias in income to offer women benefits that are 
lower compared to men. Further, the project - Promoting SLM through integrated restoration of ecosystems in Albania (planned with the Kolonja Women's Association on gender matters), used quotas to enlist women's participation in training activities. Gender-focused training, skill acquisition and access to resources and information sharing are mentioned in a few projects as ways to foster women's participation. However, it is unclear how these are planned to increase women's engagement considering that increased women's engagement is often not realised in most middle- and low-income countries where participation generally is dominated by educated, better resourced and powerful land-owning men from elite socio-cultural groups (Nederlof and Dangbégnon, 2007).

No project explicitly highlights how structural issues (e.g. discriminatory attitudes and practices originating from cultural norms) may be tackled in male-controlled settings in which females and males are embedded. A number of projects suggests that increasing women's representation in project planning and implementation would result in better outcomes for women, yet no specific criteria exist within projects' texts to verify this.

Gender analysis is incorporated in some projects from the outset to identify: activities in which women have recognised know-how and from which they can benefit through participation; and factors that enhance/hamper participation. Examples include Promoting SLM through strengthening legal and institutional framework, capacity building and restoration of most vulnerable mountain landscapes in Macedonia; and Restoring ecological corridors for multiple land and forests benefits in Western Chad. Women's participation may not imply 'right holding'; it may also not suggest fairness in land rules and tenure security (Doss et al., 2014). However, it can include attending and speaking up at meetings, holding official positions and engaging in strategic decision-making activities at the community or state level (Table 3). Among the 30 projects examined, we found that 17 (i.e. 57\%) explicitly indicate women's participation or representation in a way that portrays women as a homogenous group without considering the varied social categories of age, ethnicity and education that distinguish females.

\section{Unpacking contextual/structural gender components}

Moving beyond gendered participation and engagement, we focus on the wider contextual/structural gender dimensions of: land rights; household and farm workloads; benefit sharing; and access to resources/knowledge and incentives. Five projects clearly demonstrate these aspects (see Table 4).

These projects recognise the importance of moving beyond gendered participation to incorporate important contextual/structural gender issues, and as such offer some insights of how to enable gender inclusion in LDN projects, including the benefits of integrating gender issues and the risks of not doing so (see Table 5). Although the projects we examined target gender bias in a variety of ways following largely the GEF gender guidelines, the gender dimensions related to cost and benefit distribution, and mechanisms for safeguarding of women's rights and privileges have only been marginally considered. Despite these shortcomings, important general gender elements emerged from our analysis which deserve the greatest attention in LDN actions. These include: instituting (project) result frameworks that integrate gender-specific data to reveal women's land rights, access to and use of land, and participation in projects from inception to delivery; merging project gender plans with existing gender schemes at both local and global levels; and engaging gender experts/specialists in coordinating gender mainstreaming activities, such as the development of gender-sensitive early warning systems and budgetary provisions enabled by gender analysis. 
Table 4. Unpacking contextual/structural gender components in LDN projects

\begin{tabular}{|c|}
\hline Projects demonstrating contextual/structural gender components \\
\hline $\begin{array}{l}\text { Sustainable Land Management in the Commonwealth of Dominica } \\
\text { Focuses on reducing violence against women emanating from inequality. Its broad gender } \\
\text { focus is grounded in the country's successes in gender equity and equality as evident in the } \\
\text { strides towards the socio-economic achievement of women. By drawing on Dominica's } \\
\text { Gender Policy as the main framework for gender mainstreaming, it demonstrates the need } \\
\text { for gender equity and equality strategies of land-based projects to align with national policies } \\
\text { on gender. In this project, gender consideration encompasses three aspects: the } \\
\text { understanding of ecosystem benefits for women (benefit sharing); the initiation of knowledge } \\
\text { management activities that are gender-sensitive in terms of using sex-disaggregated data } \\
\text { and language in publications and photos to avoid presenting stereotypes; and the relative } \\
\text { positions of women, men and youth in terms of access to (and benefit from) the knowledge } \\
\text { created. }\end{array}$ \\
\hline $\begin{array}{l}\text { Generating economic and environmental benefits from sustainable land management for vulnerable } \\
\text { rural communities in Georgia } \\
\text { - Recognises women's limited access to credit (i.e. funds to purchase fertiliser, better seeds } \\
\text { and other inputs) as driving low productivity and risks of poverty among women. It prioritises } \\
\text { making contributions directly and indirectly to improve women's capacity to own land and } \\
\text { engage in land use activities that have the potential to improve their economic situation, } \\
\text { through skills development (education/training) and improved access to modern } \\
\text { technologies and knowledge on land management - the project provides an interesting } \\
\text { example of how to increase both women's incomes and social capital. }\end{array}$ \\
\hline $\begin{array}{l}\text { Sustainable Forest Management and Conservation Project in central and southern Benin } \\
\text { - Shows that women can be empowered by pursuing outcomes that: reduce women's time } \\
\text { and labour on household chores, e.g. making harvested forest/land produce available near } \\
\text { family settlements; increase capacity for women's education/training on processed forestry } \\
\text { products and sustainable forest/land management/conservation (and to use this to generate } \\
\text { alternative income); and enhance women's overall health by building accessible primary } \\
\text { healthcare centres near villages. }\end{array}$ \\
\hline $\begin{array}{l}\text { Collaborative Management for Watershed and Ecosystem Service Protection and Rehabilitation in } \\
\text { the Cardamom Mountains, Upper Prek Thnot River Basin in Cambodia } \\
\text { - Prioritises female headed households living in and depending on forests, covering: provision } \\
\text { of land use rights to support acquisition of livelihood assets for women; narrowing gender } \\
\text { disparities through access to economic and financial resources and opportunities (i.e. } \\
\text { security of land tenure, infrastructure, off-farm employment opportunities); and enhancing } \\
\text { women's voices and rights and reducing work burdens. }\end{array}$ \\
\hline $\begin{array}{l}\text { Enhancing Agro-ecological Systems in the Northern Prefectures of Central African Republic } \\
\text { Prioritises women because of their heavier productive, reproductive and community-based } \\
\text { workloads and existence of land-related gender disparities. The project targets c.8 million } \\
\text { women by focusing on: women's access to land security; enhanced organisational capacity } \\
\text { of women's producer groups; inclusive investment and growth opportunities for women; } \\
\text { gender-sensitive early warning systems; pro-women services centred on creation of } \\
\text { ecological value chains and technologies to reduce women's work time and increase their } \\
\text { productivity; and recruitment of a gender and socio-economic development specialist to } \\
\text { enhance gender mainstreaming. }\end{array}$ \\
\hline
\end{tabular}


Table 5. Associated gender-responsive LDN benefits and risks.

\begin{tabular}{l|l}
\hline \multicolumn{1}{c|}{ Focus/benefits of a gender-responsive LDN } & \multicolumn{1}{|c}{ Risks of ignoring gender issues in LDN } \\
\hline $\begin{array}{l}\text { Identifying legitimate stakeholders and capturing } \\
\text { relevant experiences/skills/knowledge of women } \\
\text { and men. }\end{array}$ & $\begin{array}{l}\text { Increased women's work burden; reinforcing } \\
\text { their status as victims of degradation rather than } \\
\text { champions of restoration. }\end{array}$ \\
$\begin{array}{l}\text { Understanding and accounting for the different } \\
\text { women's and men's roles, rights and } \\
\text { responsibilities as land users and managers, } \\
\text { including their particular land access and use } \\
\text { patterns. }\end{array}$ & $\begin{array}{l}\text { Imprecise identification of i) men and women } \\
\text { stakeholders in land use practices; ii) socially- } \\
\text { just options for neutrality interventions; and iii) } \\
\text { benefit sharing leading to increased } \\
\text { marginalisation of women in decision making. }\end{array}$ \\
$\begin{array}{l}\text { Clear identification of drivers of degradation, } \\
\text { guaranteed accuracy of information and potential }\end{array}$ & $\begin{array}{l}\text { Draw back in project sustainability and long-term } \\
\text { effectiveness, e.g. due to maintenance of } \\
\text { existing inequality in tenure security. }\end{array}$ \\
$\begin{array}{l}\text { synergies/coordination to address challenges. } \\
\text { Joint planning, implementation and monitoring of } \\
\text { LDN options and outcomes, ensuring sustainable }\end{array}$ & $\begin{array}{l}\text { Discriminatory planning systems and risk of } \\
\text { unfair cost/benefit sharing reinforcing social } \\
\text { land conservation/restoration and equitable } \\
\text { divisions. } \\
\text { sharing of benefits e.g. in line with a human } \\
\text { rights-based approach to development. }\end{array}$ \\
\hline
\end{tabular}

\section{ADVANCING GENDER-RESPONSIVE LDN}

Since the recent decade, awareness and recognition of gender biases, e.g. in the way landbased activities are planned and executed, have grown significantly. Several projects examined in this paper suggest that SLM and land restoration are either gender-sensitive or gender blind (Table 6). To achieve the goal of a land degradation neutral world that advances gender equality would require uncovering innovative entry points for integrating gender concerns into LDN actions (see Figure 1). Here, we highlight valuable entry points for integrating gender issues into LDN efforts, focusing on the importance of engaging key constituencies/voices and stakeholder groups, as well as global gender norms/principles and financial mechanisms, to support gender equality promoting efforts. We also identify opportunities that exist to maximise women's expertise/skills in pursuing gender-responsive LDN actions.

\section{Narrowing gender disparities and empowering women as agents of change}

At the core of the global action to achieve gender-responsive LDN are transformative SLM and restoration/rehabilitation projects and a LDN finance mechanism that promotes and safeguards women's and men's rights to resources and opportunities that enhance their quality of life (Figure 1). Gender-responsive LDN explicitly accounts for human rights and addresses gender equality concerns, empowering women to become agents of change in addressing land degradation. A key promising point of entry for integrating a gender perspective that empowers women would be through the LDN interlinked hierarchy of responses that seek to avoid, reduce and reverse land degradation (see Okpara et al., 2018), as well as through gender-based assessment/monitoring of LDN indicator components (land cover, productivity and carbon storage). Gender-sensitive actions along the LDN response hierarchy can enable gender equality and increase women's capacity to participate in LDN projects if socio-cultural norms are aligned with human rights principles. 
Table 6. A summary table showing the 30 projects selected based on three attributes: (i) gender participation and engagement (GD1); (ii) contextual/structural gender components (GD2); and (iii) gender inaction, i.e. absence of specific gender content (GD3) [Note: $(++)=$ explicitly indicated/captured; (+) slightly indicated/captured; (-) = not indicated/captured].

\begin{tabular}{|c|c|c|c|}
\hline Project $^{*}$ & GD1 & GD2 & GD3 \\
\hline Land degradation neutrality of mountain landscapes in Lebanon & ++ & + & - \\
\hline Sustainable Land Management Project in the Commonwealth of Dominica & ++ & ++ & - \\
\hline Promoting SLM through Integrated Restoration of Ecosystems in Albania & ++ & - & - \\
\hline Community-based Sustainable Dryland Forest Management in Gambia & ++ & - & - \\
\hline Improving Sustainable Management of Natural Resources in Niger & ++ & + & - \\
\hline Sustainable forest and landscape management in Bosnia and Herzegovina & ++ & + & - \\
\hline $\begin{array}{l}\text { Integrated community-based forest and catchment management through an } \\
\text { ecosystem service approach in Thailand }\end{array}$ & ++ & - & - \\
\hline $\begin{array}{l}\text { Mainstreaming biodiversity into the management of the coastal zone in the } \\
\text { Republic of Mauritius }\end{array}$ & ++ & ++ & - \\
\hline $\begin{array}{l}\text { Using SLM to improve the integrity of the Makgadikgadi ecosystem and to } \\
\text { secure the livelihoods of rangeland dependent communities in Botswana }\end{array}$ & ++ & + & - \\
\hline $\begin{array}{l}\text { Promoting SLM through strengthening legal and institutional framework, } \\
\text { capacity building and restoration of most vulnerable mountain landscapes in } \\
\text { Macedonia }\end{array}$ & ++ & + & - \\
\hline $\begin{array}{l}\text { Restoring ecological corridors for multiple land and forests benefits in Western } \\
\text { Chad }\end{array}$ & ++ & - & - \\
\hline $\begin{array}{l}\text { Sustainable rangeland management for biodiversity conservation and climate } \\
\text { change mitigation in Jordan and Egypt }\end{array}$ & ++ & ++ & - \\
\hline $\begin{array}{l}\text { Generating economic and environmental benefits from sustainable land } \\
\text { management for vulnerable rural communities in Georgia }\end{array}$ & + & ++ & - \\
\hline $\begin{array}{l}\text { Sustainable Forest Management and Conservation Project in central and } \\
\text { southern Benin }\end{array}$ & + & ++ & - \\
\hline $\begin{array}{l}\text { Collaborative Management for Watershed and Ecosystem Service Protection } \\
\text { and Rehabilitation in the Cardamom Mountains, Upper Prek Thnot River } \\
\text { Basin in Cambodia }\end{array}$ & + & ++ & - \\
\hline $\begin{array}{l}\text { Enhancing Agro-ecological Systems in the Northern Prefectures of Central } \\
\text { African Republic }\end{array}$ & + & ++ & - \\
\hline $\begin{array}{l}\text { Piloting Innovative Investments for Sustainable Landscapes in Brazil, } \\
\text { Indonesia and Liberia }\end{array}$ & + & ++ & - \\
\hline Sustainable Land and Water Management in Ghana & + & - & - \\
\hline $\begin{array}{l}\text { Scaling up a multiple benefits approach to enhance resilience in agro- and } \\
\text { forest landscapes of Mali's Sahel regions }\end{array}$ & + & ++ & - \\
\hline $\begin{array}{l}\text { Integrated Watershed Management for improved agro-pastoral livelihoods in } \\
\text { the Sepabala sub-catchment in Lesotho }\end{array}$ & ++ & + & - \\
\hline $\begin{array}{l}\text { Sustainable and Integrated landscape Management of the Western Area } \\
\text { Peninsula in Sierra Leone }\end{array}$ & ++ & + & - \\
\hline Sustainable Land Management for Increased Productivity in Armenia & ++ & - & - \\
\hline Sustainable Land Management in Chile & - & - & ++ \\
\hline $\begin{array}{l}\text { Participatory Sustainable Land Management in the Grassland Plateaus of } \\
\text { Western Madagascar in Madagascar }\end{array}$ & ++ & + & - \\
\hline ffset and Mitigation in Western Mongolia & + & + & - \\
\hline Sustainable management of Namibia's forested land in Namibia & ++ & + & - \\
\hline Sustainable Forest and Land Management Project in Kyrgyzstan & - & - & ++ \\
\hline Strengthening the National Protected Areas System of Swaziland & + & + & - \\
\hline $\begin{array}{l}\text { Strengthening Management Effectiveness and Generating Multiple } \\
\text { Environmental Benefits within and around Protected Areas in Zambia }\end{array}$ & + & - & - \\
\hline Comprehensive and integrated management of natural resources in Nigeria & - & - & ++ \\
\hline
\end{tabular}

"Note: Refer to Table S1 in the supplementary material for a detailed description of each project. 


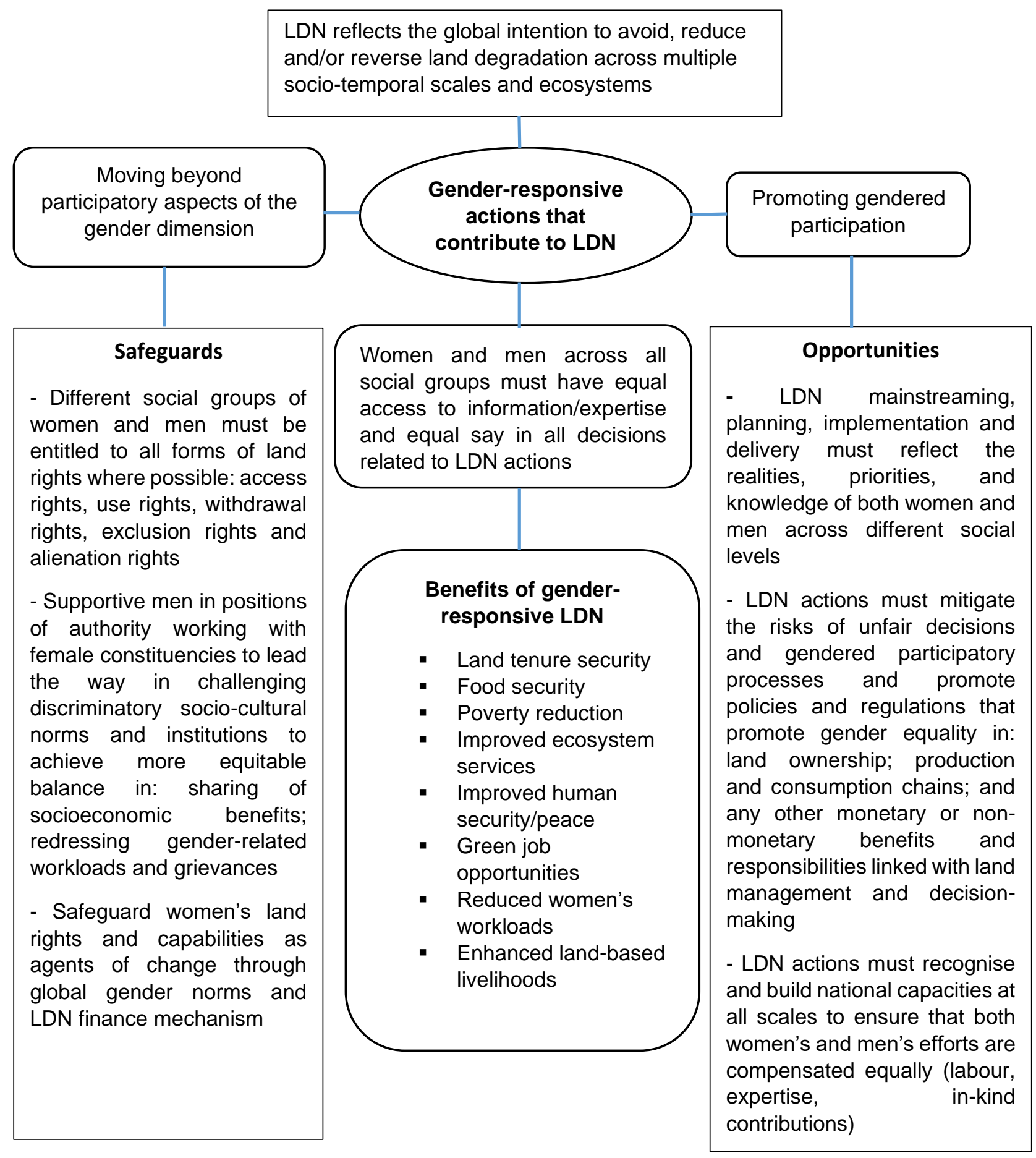

Figure 1. Gender-responsive land degradation neutrality framework

The majority of the LDN-related projects we examined limit women's empowerment only to participation in decision-making, overlooking actions that can empower women to: promote and protect their rights, manage their workloads, and use their knowledge to negotiate for fairer laws and policies. Priorities for a strategic gender-responsive approach that enables female empowerment can be better shaped by: i) ensuring that project plans align with existing country-level women's empowerment processes (such plans should not constitute an 
additional process); and ii) linking the land and gender indicators captured in the SDGs, specifically indicators 1.4.2, 5.a.1 and 5.1.2 which account for gender-differentiated roles and responsibilities, heavy women's workloads and barriers to women's land rights. In addition, engaging gender experts in LDN projects can facilitate a nuanced context analysis of these indicators across diverse socio-cultural and geographical settings in ways that can systematically integrate gender varied dimensions in refining meaningful LDN targets at the national level (Orr et al., 2017; UN Women, 2018).

Assumed homogeneity of women as a group is prevalent in the majority of projects examined. This has tended to undermine considerations for key social differentiators such as class, age, ethnicity and income status. Adopting a broader gender-responsive approach would require that answers from more gender-related socio-cultural questions (such as who should be included in LDN actions; who should negotiate LDN cost/benefits and who should benefit and how; and how much is fair and just) be synthesised to inform the planning, execution, and monitoring/evaluation of LDN initiatives (Thompson-Hall, 2016).

\section{Removing structural and institutional barriers that limit women}

The literature on gender equality in natural resource contexts reveals that discriminatory gender norms and practices relating to resource control (Agarwal, 2001), exclusionary agendas and institutions (Arora-Jonsson, 2011) and skewed financial and information sharing mechanisms (Larson et al., 2015), among other factors, often undermine gender equality/relations. To tackle discriminatory gender norms/practices and institutional barriers at various scales would require the following.

First, men in positions of authority need to work with female role models and agencies (e.g. the UNCCD mechanisms on gender) to: spearhead gender-equitable conditions that challenge discriminatory socio-cultural norms and institutions (Mwangi, 2017); and promote and safeguard the rights of women so that their views, interests and priorities are adequately reflected in LDN planning and implementation, fostering equal sharing of LDN-related benefits between men and women across various social strata (Chant, 2008).

Second, there is a need to develop LDN-facing policies that align with relevant global conventions on gender rights, e.g. to mandate cultural changes and movement away from patriarchal land ownership norms towards practices that enable equally balanced gender rights. One way to do this would be to incorporate directives domiciled in the Convention on the Elimination of Discrimination against Women (CEDAW) to guide the planning and implementation of LDN projects. Article 4 of the CEDAW instructs parties to modify sociocultural practices and conducts that marginalise women, and to take appropriate measures to uphold rural women's rights to land tenure security as part of efforts to eliminate all forms of discrimination and stereotypes against women (see CEDAW, 2004). A good example of a land-based intervention where the CEDAW protocol was used to spur women's rights and gender equality in ecological restoration is the Azraq Oasis Restoration Project in Jordan (see Broeckhoven and Cliquet, 2015).

Third, a mix of environment-related conventions and instruments advocating for human rights and gender equality (e.g. the Convention on Biological Diversity (CBD), UNCCD and Ramsar Convention on Wetlands) can serve as guiding instruments for gender mainstreaming in LDN processes. The CBD provides "how to" tools for gender integration applicable to land-based projects, emphasising steps to be taken to integrate women's and men's concerns and experiences in project planning (see CBD-GPA, 2014). In addition, several UNCCD protocols, in particular the Gender Plan of Action (see UNCCD-GPA, 2018) and the Advocacy Policy Framework (see UNCCD-APF, 2017) promote gender-specific ways in which to tackle land degradation and achieve the LDN target. The Ramsar Convention on Wetlands acknowledges gender and social issues as essential in efforts to manage wetlands (see Ramsar, 2018). 
Further, the United Nations Environment Programme (UNEP) provides a gender checklist to ensure gender is integrated into UNEP-funded projects (see IUCN, 2012). Adapting the checklist to the LDN process can provide a gender framework to guide LDN actions. Several other international policy tools and documents (e.g. the UN Declaration on the Rights of Indigenous Peoples ${ }^{8}$; the Voluntary Guidelines on the Responsible Governance of Tenure of Land, Fisheries and Forests ${ }^{9}$ under the coordination of the Committee on World Food Security and the FAO; the International Covenant on Economic, Social and Cultural Rights ${ }^{10}$; and the Beijing Declaration and Platform for Action $^{11}$ ) further reinforce a focus on women's empowerment and gender equality in rights, access and control of natural resources, presenting cross-cutting issues for advancing gender-responsive actions.

While there are limited strategic patterns for tackling structural and institutional barriers that limit women at different levels in the projects we examined, merging gender-related conventions and commitments with country-level gender equality mechanisms can provide a pathway for advancing gender-responsive LDN. Such a process grounded in a logical framework to follow-up on the status of gender equality in LDN-related national initiatives (see Table S3) can be initially supported by a dedicated UNCCD Women's agency and national women's right associations (with relevant expertise), and by promoting mandated gender analysis of the LDN Target-Setting Programme (LDN-TSP) to inform the development of transformative gender-responsive LDN projects.

An example of a national gender equality mechanism/agency rooted in equality and human dignity is Kenya's National Gender and Equality Commission ${ }^{12}$ - which promotes gender and human rights, and laws on land, inheritance and marital property by challenging power dynamics through democratic participation, accountability and transparency. Innovative approaches for tackling structural and institutional barriers to land rights exist in many countries, e.g. use of land certificate programmes in Ethiopia (Melesse et al., 2015); use of communal land boards comprising women and men in Namibia to assist women to successfully acquire titles to traditional land (PLAAS, 2015); and systematic land registration procedures in Cambodia that enable distribution of land titles jointly to husband and wife (Cismas and Paramita, 2015). The Chipko Movement in India and the Green Belt Movement in Kenya (see Samandari, 2017)) are two well-known examples that offer good practices that can serve as models and inspiration for promoting gender equality in LDN.

\section{Harnessing the gender elements in different finance mechanisms to inform the LDN fund}

Several international finance mechanisms now consider gender-specific issues and action plans before projects are funded, including projects under the UNCCD and other Rio Conventions. Both the Global Environment Facility (GEF) and the Green Climate Fund (GCF) have a gender equality guide with requirements for national-level project planning and financing (see GEF, 2015; GCF, 2017). Many gender elements in the projects we analysed comply with the GEF gender equality action requirements, such as to: integrate gender analysis in projects; undertake stakeholder consultation; engage gender experts, and women and women's groups to foster gender equality in project design and execution; develop and collect sex-disaggregated data; and initiate gender-related budget items for gender-specific activities. An independent LDN fund has recently been created to finance SLM and land restoration projects (UNCCD News, 2017), although it has been criticised as tending to

\footnotetext{
${ }^{8}$ UNDRIP, 2007

${ }^{9} \mathrm{FAO}, 2012$

10 ICESCR, n.d

11 BDPA, 1995

12 NGEC, 2013
} 
prioritise 'returns on investment' over a gender equality ideal that promotes benefit-sharing and financial access to women and women's groups (UN Women, 2018). GEF and GCF finance mechanisms, including the UNCCD-GPA framework and other gender-related conventions and commitments, can provide guidance and institutional legitimacy for creating a rights-based and gender-responsive LDN funding landscape that delivers multiple benefits to women.

\section{CONCLUSIONS}

Promoting gender equality and female empowerment can have a wide-ranging positive effect on achievement of land degradation neutrality (LDN) in many low and middle-income countries where women face gender-related barriers. Although land degradation is known to have a strong gender component, to date gender disparities in efforts to avoid, reduce and reverse land degradation have hardly been considered in LDN programming. We argue that to achieve LDN in regions with deeply entrenched socio-cultural norms would require LDN to be genderresponsive, accounting for the varied gender components of land degradation. Three LDNrelated projects examined in this study excluded gender issues (i.e. they appear to be completely gender blind). This does not suggest (potential) project failure; crucially LDN efforts that support or promote gender equality and/or account for women's interests may not always be the most efficient option to reach all LDN targets (e.g. ecosystems may be restored but food security is undermined). At the minimum, gender-responsive LDN can enhance greater equality in decision-making at various levels, but may not contribute towards addressing discriminatory land practices if it does not challenge national land tenure systems that undermine women's land rights.

Initiatives to avoid, reduce and/or reverse land degradation in the context of the SDGs can become gender-responsive by using a generic LDN gender framework that is adaptable to local contexts (e.g. see Figure 1). Such initiatives can thrive on a gender-sensitive finance mechanism that is backed by human rights principles/laws and institutions, and targeted to: reduce women's workload; link land rights to land ownership and safeguard tenure security; enable gender review and analysis to foster information sharing; mandate provision of incentives and training to enhance women's resilience to land degradation and climate change; and encourage national bodies to promote gender-responsive LDN actions. Indeed, recognising and securing women's rights represent an explicit cross-cutting catalyst for confronting rural poverty (Goal 1), achieving family food/nutrition security (Goal 2), and reaching gender equality (Goal 5).

Planning and implementing gender-responsive LDN requires multi-stakeholder collaboration and training. Women, in particular, need to be trained in the skills required to engage in LDN planning and execution. Identifying gender needs and gaps early on at project inception phase can facilitate the development of sound gender capacity-building programmes to develop women's skills in identifying opportunities to articulate their priorities and advocate for their rights; as well as developing indicators to ensure that gender-based skill gaps are closed and the entry points for women's engagement and empowerment are identified starting from the project inception phase throughout the project's life cycle. At the same time, since rural women hold valuable ecological knowledge on land use and management, promoting gender-specific ways of documenting and preserving women's knowledge should be central to LDN efforts. Increasing women's presence in high-level community-based committees, including raising the number of women contributing to important land use plans and decisions will play a pivotal role in closing the gender gap in land ownership and management, and in revolutionising actions towards a land degradation neutral world that is gender-responsive. 


\section{REFERENCES}

Agarwal, B. (2001). Participatory exclusions, community forestry, and gender: an analysis for South Asia and a conceptual framework. World Development, 29,1623-1648. https://doi.org/ 10.1016/S0305-750X(01)00066-3

Arora-Jonsson, S. (2011). Virtue and vulnerability: Discourses on women, gender and climate change. Global Environmental Change, 21(2), 744-51. https://doi.org/10.1016/j.gloenvcha.2011.01.01.005

BDPA (1995). Beijing Declaration and Platform for Action. Beijing: UN Women. Retrieved from http://www.un.org/womenwatch/daw/beinjing/pdf/BDPfA\%20E.pdf

Broeckhoven, N., \& Cliquet, A. (2015). Gender and ecological restoration: Time to connect the dots. Restoration Ecology, 23(6),729-736. https://doi.org/10.1111/rec.12270

CBD-GPA (2014). Guidance on mainstreaming gender into work under the Convention on Biological Diversity. Montreal, Canada: UN Convention on Biological Diversity. Retrieved from https://www.cbd.int/doc/meetings/wgri/wgri-05/information/wgri-05-inf-17-add1-en.pdf

CEDAW (2004). General recommendation on temporary special measures. The Convention on the Elimination of All Forms of Discrimination against Women, No. 25, article 4, paragraph 1.,. Retrieved from http://www.un.org/womenwatch/daw/cedaw/recom mendations/index.html

Chant, S. (2008). Dangerous equations? How female-headed households became the poorest of the poor: Causes, consequences and cautions. IDS Bulletin, 35(4),19-26. https://doi.org/10.1111/j.1759-5436.2004.tb00151.x

Chasek, P., Safriel, U., Shikongo, S., \& Fuhrman, V. (2015). Operationalizing zero net land degradation: the next stage in international efforts to combat desertification? Journal of Arid Environment, 112, 5-13. https://doi.org/10.1016/j.jaridenv.2014.05.020

Cismas, I., \& Paramita, P. (2015). Large-scale land acquisitions in Cambodia: Where do (human rights) law and practice meet? International Development Policy, 6. https://doi.org/ 10.4000 / poldev.2051

Doss, C., Kovarik, C., Peterman, A., Quisumbing, A., \& van den Bold, M. (2015). Gender inequalities in ownership and control of land in Africa: myth and reality. Agricultural Economics, 46, 403-434. https://doi.org/10.1111/agec.12171

Doss, C., Meinzen-Dicka, R., Quisumbinga, A., \& Theis, S. (2018). Women in agriculture: Four myths. Global Food Security, 16, 69-74. https://doi.org/10.1016/j.gfs.2017.10.001

Doss, C., Summerfield, G., \& Tsikata, D. (2014). Land, gender and food security. Feminist Economics, 20 (1), 1-23. https://doi.org/10.1080/13545701.2014.895021

FAO (2009). Bridging the gap: FAO's Programme for Gender Equality in Agriculture and Rural Development. Rome, Italy: FAO

FAO (2012). The Voluntary Guidelines on the Responsible Governance of Tenure of Land, Fisheries and Forests. Rome, Italy: FAO. Retrieved from http://www.fao.org/docrep/016/i2801e/i2801e.pdf 
FAO (2018). Why is gender equality and rural women's empowerment central to the work of FAO? Rome, Italy: FAO. Retrieved from http://www.fao.org/gender/background/en/

GCF (2017). Mainstreaming Gender in Green Climate Fund Projects. Korea: Green Climate Fund. Retrieved from https://www.greenclimate.fund/documents/20182/194568/Guide lines_GCF_Toolkit_Mainstreaming_Gender.pdf/860d1d03-877d-4c64-9a49-c0160c794ca7

GEF (2015). Gender Equality Action Plan. Washington DC: Global Environment Facility. Retrieved from https://www.thegef.org/publi cations/gender-equality-action-plan

Hirao, K. (2016). Environment and gender. The Wiley Blackwell Encyclopaedia of Gender \& Sexuality Studies. https://doi.org/10.1002/9781118663219.wbegss706

ICESCR, n.d. International Covenant on Economic, Social and Cultural Rights. New York: ICESCR. Retrieved from https:www.ohchr.org/EN/Professionallnterest/Pages/CESCR. aspx.

IPBES Report (2018). Summary for policymakers of the thematic assessment report on land degradation and restoration of the Intergovernmental Science-Policy Platform on Biodiversity and Ecosystem Services. R. Scholes, L. Montanarella, A. Brainich, N. Barger, B. ten Brink, M. Cantele, B. Erasmus, J. Fisher, T. Gardner, T. G. Holland, F. Kohler, J. S. Kotiaho, G. Von Maltitz, G. Nangendo, R. Pandit, J. Parrotta, M. D. Potts, S. Prince, M. Sankaran and L. Willemen (eds.). Bonn, Germany: IPBES secretariat pages 32

IUCN (2012). UNEP's Gender Plan of Action. Switzerland: IUCN. Retrieved from https://portals.iucn.org/union/sites/union/files/doc/uneps_gender_plan_of_action.pdf

Kondylis, F., Mueller, V., Sheriff, G., \& Zhu, S. (2016). Do female instructors reduce gender bias in diffusion of sustainable land management techniques? Experimental evidence from Mozambique. World Development, 48, 436-449. https://doi.org/10.1016/j.worlddev.2015.10.036

Larson, A., Dokken, T., Duchelle, A., Atmadja, S., Resosudarmo, I., Cronkleton, P., \& Selaya, G. (2015). The role of women in early REDD+ implementation: Lessons for future engagement. International Forestry Review, 17(1),43-65. https://doi.org/10.1505/14655481581472 5031

Meinzen-Dick, R., Quisumbing, A., Doss, C., \& Theis, S. (2017). Women's land rights as a pathway to poverty reduction: Framework and review of available evidence. Agricultural Systems. https://doi.org/10.1016/j.agsy.2017.10.009

Melesse, M., Dabissa A., \& Bulte E. (2015). Joint Land Certification Programs and Women's Empowerment: Evidence from Ethiopia. Paper presented for "CSAE Conference 2015: Economic Development in Africa”, March 22 - 24, 2015, St Catherine's College, University of Oxford, UK

Mwangi E. (2017). Moving the needle: Advancing gender equality in Uganda. Forests News. Bogor, Indonesia: Center for International Forestry Research. Retrieved from https://forestsnews.cifor.org/48873/moving-the-needle-advancing-gender-equality-in-uganda ?fnl=en

Nederlof, E., \& Dangbégnon, C. (2007). Lessons for farmer-oriented research: experiences from a West African soil fertility management project. Agriculture \& Human Values, 24(3), 36987. https://doi.org/10.1007/s10460-007-9066-0 
NGEC (2013). National Gender and Equality Commission: Strategic Plan 2013-2015, Nairobi: the Kenya Gender Commission. Retrieved from https://www.ngeckenya.org/Downloads/NGE C-Strategic-Plan\%202017-2022.pdf

Okpara, U. T., Stringer, L. C., Akhtar-Schuster, M., Metternicht, G., Dallimer, M., \& RequierDesjardins, M. (2018). A social-ecological systems approach is necessary to achieve land degradation neutrality, Environmental Science \& Policy, 89, 59-66. https://doi.org/10.10.16/j.envsci.2018. 07.003

Orr, B. J, Cowie, A. L, Castillo Sanchez, V. M, Chasek, P., Crossman, N. D, Erlewein, A., Louwagie, G., Maron, M., Metternicht, G.I, Minelli, S., Tengberg, A. E., Walter, S., \& Welton, S. (2017). Scientific conceptual framework for land degradation neutrality. A Report of the Science-Policy Interface. United Nations Convention to Combat Desertification (UNCCD), Bonn, Germany

PLAAS (2015). Understanding land acquisitions in Namibia's communal land: impacts and policy implications. PLASS Policy Brief 39. Retrieved from http://www.plaas.org.za/ sites/default/files/publications-pdf/PLAAS_ADC\%20policy\%20brief_Namibia_Web39_0.pdf

Ramsar (2018). Draft resolution on gender and wetlands. Gland, Switzerland: RAMSAR. Retrieved from http://www.ramsar.org/sites/default/files/documents/library/sc54com9_gender_e_clean.pdf

Samandari, A. (2017). Gender-sensitive land degradation neutrality. UNCCD Global Land Outlook Working Paper, pgs. 1-18. Retrieved from https://knowledge.uncc

d.int/sites/default/files/2018-06/3.\%20GenderResponsive\%2BLDN_A_M_Samandari.pdf

Sietz, D., Fleskens, L., \& Stringer, L. (2017). Learning from non-linear ecosystem dynamics is vital for achieving land degradation neutrality. Land Degradation \& Development, 28, 23082314. https://doi.org/10.1002/ldr.2732

Stavi, I., \& Lal, R. (2015). Achieving zero net land degradation: challenges and opportunities. Journal of Arid Environments, 112, 44-51. https://doi.org/10.1016/j.jaridenv.2014.01.016

Stringer, L., Reed, M., Fleskens, L., Thomas, R., Le, Q., \& Lala-Pritchard, T. (2017). A new dryland development paradigm grounded in empirical analysis of dryland systems science. Land Degradation \& Development, 28, 1952-1961. https://doi.org/10.1002/ldr.2716

Thompson-Hall, M. (2016). Land restoration, agriculture and climate change: enriching gender programming through strengthening intersectional perspective, in Chabay, I., Frick, M., Helguson, J., Land Restoration: Reclaiming Landscapes for a Sustainable Future, Chapter: 6.1, pp 421-430. https://doi.org/10.1016/B978-0-12-801231-4.00028-8

UN Women (2018). Towards a gender-responsive implementation of the united nations convention to combat. Retrieved from http://www.unwomen.org//media/headquarters/attachments/sections/library/publications/2018/towards-a-gender-respo nsive-implementation-of-un-convention-to-combat-desertificationen.pdf?la=en\&vs=3803

UNCCD News (2017). LDN Fund officially launched. Bonn, Germany: UNCCD. Retrieved from https://www.unccd.int/news-events/ldn-fund-officially-launched

UNCCD (2017). Turning the tide: the gender factor in achieving land degradation neutrality. Bonn, Germany: UNCCD. Retrieved from https://www.unccd.int/sites/default/files/docu ments/2017_Gender_END.pdf 
UNCCD-APF (2017). Draft advocacy policy frameworks: Gender, Drought and Sand and Dust Storms. Note by the secretariat. Germany: UNCCD. Retrieved from https://www.unccd.int/official-documents/cop-13-ordos-china-2017/iccdcop1319.

UNCCD-GPA (2018). Gender Plan of Action. Bonn: UNCCD. Retrieved from https://www.unccd.int/publicat ions/gender-action-plan

UNDRIP (2007). United Nations Declaration on the Rights of Indigenous Peoples. New York: UN Office. Retrieved from http://www.un.org/esa/socdev/unpfii/documents/DRIPS_en.pdf

Waddington, H., White, H., Snilstveit, B., Hombrados, J., Vojtkova, M., Davies, P., Bhavsar, A., Eyers, J., Koehlmoos, T., Petticrew, M., Valentine, J., \& Tugwell, P. (2012). How to do a good systematic review of effects in international development: a tool kit, Journal of Development Effectiveness, 4(3), 359-387. https://doi.org/10.1080/19439342.2012.711765

\section{SUPPORTING INFORMATION}

\section{A. Appendix}

Appendix S1. Literature review

\section{Gender and land degradation: conceptual and theoretical perspectives}

Land is both a capital asset and an important cultural resource. It is often central to communal/gender power struggles and debates on women's empowerment or discrimination (Doss et al. 2018). Perceptions of gender and land are deeply rooted in cultures, vary widely within and between societies, and are dynamic. Gender relates to socially constructed differences between women and men on the basis of their roles, responsibilities, behaviours, daily activities and attributes. Eco-feminists conceive the links between land use, ownership and management as substantially mediated through gender, focusing in particular on women as victims of land degradation (Doss et al., 2015; Hirao, 2016). Power is required to control land and those with power can reinforce gender bias in multiple ways. Gender bias exists in: land rights; agricultural/domestic labour divisions; access to resources and incentives; participation in decision-making opportunities; and sharing of costs/benefits of intervention projects (Meinzen-Dick et al., 2017). Such bias can fuel inequalities and social injustices, and can be tied to the ways women and men degrade the land (FAO, 2009). The notion of inequality in the theory and practice of land management and restoration/rehabilitation does not suggest that women and men are unequal humans, but rather that their roles, responsibilities, opportunities and realities are not dependent on whether they were born female or male (FAO, 2018).

Land supports humanity in many ways, yet inequality in land rights remains deeply rooted in many regions with enshrined male-controlled resource structures (Doss et al., 2015). In such regions (e.g. Africa and Asia), land rights are highly coveted, contested and negotiated. Although $>95 \%$ of all economically active women in rural areas use land-based resources to support their families, supplying $60-80 \%$ of food, and holding valuable indigenous knowledge on land management, $<20 \%$ of women own or have secure control over land (Samandari, 2017; Doss et al., 2018). Traditional patriarchal norms favour men but curtail the bundle of rights that women deserve (i.e. rights to own, inherit, bequeath and/or manage land) (Rao, 2017). In some places, women only have access to land depending on the strength of their relationship to the male owner (UN Women, 2018). Weak legal and social protections for women's land use has created conditions where women's needs, realities and knowledge are 
overlooked in land matters. Concurrently, unequal power relations deprive women of their legal rights as "value-chain" actors - e.g. to control tree planting that can potentially prevent soil degradation and enhance land productivity (Johnson, 2003). Eco-feminists have long critiqued structural inequalities that give men control over land resources and the emergent benefits, arguing that discriminatory land rights can spur land degradation where land use choices rest with a male owner who (potentially) lacks knowledge of land conservation that the woman has acquired over time through her work on the land (Agarwal, 2010; Doss et al., 2014; Johnson et al., 2016). Similarly, male ownership and control of households' land, including control over decision-making and resource allocation, means women are frequently less able to invest in more sustainable land management practices (Landesa, 2015).

Gendered family workloads often make women responsible for household maintenance, as well as food security, health/child care and care of other family members. Although women make up $43 \%$ of the agricultural labour force (increasing to $70-80 \%$ in many developing countries), stereotypical gender roles undermine women's capacity to significantly contribute to land improvement (WFO, 2013). Women often strive to supplement their family's limited or declining food supplies by taking up petty trading or selling their labour to wealthier farmers for income to meet immediate household subsistence needs (Verma, 2001) - in addition to carrying out reproductive and care-giving duties (Doss et al., 2018). Out-migration of men in search of livelihood opportunities can transfer further workloads to women, compelling them to juggle multiple duties, such as animal husbandry, managing pasturelands and/or growing of cash crops, previously undertaken by the men (Aguilar, 2014). These responsibilities require additional time, energy, efforts, knowledge and resources, which often women lack and cannot access (UNCCD, 2017). Male out-migration curtails the time and energy women can invest in (sustainable) land management, undermining their ability to make meaningful land improvement choices. This makes women victims of land degradation - particularly in societies where women have restricted access to essential resources and incentives needed to improve land productivity in the face of degradation.

Gender bias in access to resources and incentives links to paucity of land rights in largely agrarian communities. Securing land rights and tenure is a pre-condition for attracting new agricultural innovations and tools, soil enriching seeds and fertiliser, and agronomic knowledge, and for driving important changes such as income growth and livelihood wellbeing. Paucity of land rights limits access to credit and extension services (also technical assistance and training). Worldwide, women hold $<10 \%$ of credit available to smallholder agriculturalists, comprise only $15 \%$ of agricultural extension officers, receive $5 \%$ of rural extension services, and are only half as likely as men to use technologies and improved farm inputs/crop varieties (FAO, 2011). Such gender bias can reinforce female poverty (Orr et al., 2017) and can feed into land degradation (UNCCD, 2016). Over 40\% of degraded land in recent years is in impoverished regions, largely in rural communities in Africa and Asia (UNCCD, 2017; IPBES Report, 2018). Poverty influences women's ability to prioritise land management and restoration/rehabilitation (Kissinger et al., 2012), disproportionately undermining their contributions to global efforts to tackle land degradation (Nelson et al., 2015).

The context in which SLM and restoration is practiced can affect women's access to and control over benefits, and contribution to decision-making. For example, deeply entrenched gender-based discrimination in statutory/customary systems in Africa fuel unequal power relations, creating barriers to women's full involvement and effective participation in land planning and policy making processes (UNCCD, 2017). Worldwide, only $13 \%$ of female land users contribute to decision-making on agricultural land (FAO, 2011), undermining their capacity to secure opportunities like men in leadership roles at all levels. UN-REDD+ and forest landscape restoration studies show that where the priority is to promote cash crop trees for land management, men often seem to benefit more financially (den Bensten, 2011). In the absence of suitable cash/non-cash related benefits for women (e.g. in long-term land-related schemes), women would decline to participate (Pham, 2016). Despite that women's labour 
and skills are often mobilised in restoration/rehabilitation activities, they usually have less access to and control over benefits than men (Ramsay, 2017). Land-based schemes that are gender-blind heighten women's work burden by excluding them from important benefits (Larson et al., 2015).

Addressing these gender gaps offers a route to effectively respond to land problems and strengthen women's and men's capacities as agents of change on land matters (BRIDGE, 2011). Although patriarchal systems of land tenure and divisions of agricultural/domestic labour undermine rural women's land ownership rights, they do not take away women's affinity to land. Ecological feminism presents nature (e.g. land) as a feminine entity, suggesting women's interaction and care for nature is shaped by their motherly instinct and biological empathy (Agarwal, 2010). By their close tie to land, traditional knowledge in farming, positionality as land users, and commitment to environmental initiatives, women are uniquely and differentially equipped for environmental stewardship (Villamor et al., 2014). Similarly, women in many regions are involved in leading protests (i.e. environmental movements) against environmental damages and pollution (see GBM, 2018). They comprise $60-80 \%$ of mainstream environmental NGO membership and even more in grassroots organisations supporting e.g. forest conservation and farmland conservation schemes (Hirao, 2016). Compared to men, women hold stronger pro-environmental values, beliefs, and attitudes (Aguilar, 2014).

Gender blind land-based initiatives have sometimes exacerbated gender inequalities, heightening women's burden and undermining their voices, agency and access to extension services (Agarwal, 2001; Nightingale, 2002), pushing women into land use/management decisions that undermine land productivity. In contrast, Chhatre et al. (2012) and Quisumbing and Kumar (2014) reveal that bequeathing land to women and securing their land rights and access to credits correlates positively with women's willingness to commit time, energy and knowledge to grassroots land management and restoration/rehabilitation. Tenure security reduces women's workloads, enhancing their power to bargain and make decisions about land (Meinzen-Dick et al., 2017). Because gender equality is not only a human right but also catalytic to environmental progress, it is well established, at least in theory, that closing the gender gaps should constitute the core premise of land policies, strategies, and action plans (UNEP, 2012).

While awareness of gender dimensions related to land has risen significantly, current LDN literature is scarce concerning: i) how LDN actions can help address gender disparities alongside its primary goals to avoid, reduce and reverse land degradation; ii) the advantage(s) of bringing gender into mainstream LDN processes; and iii) the risks we face by not doing so. Implementing, achieving and maintaining LDN in places with deeply entrenched patriarchal norms and traditional values underscores the need for a better understanding of these issues. Gender consideration in LDN offers considerable opportunities for pursuing LDN commitments that perpetuate equal participation of women and men (Samandari, 2017), and for incentivising poor rural women to contribute to and benefit from LDN outcomes (Orr et al., 2017). Pursuing LDN on the basis of indigenous and statutory land use practices and tenure relations can help to identify: i) different land user groups with formal and informal rights; ii) strategies for collaborative negotiations to address areas of social-cultural challenges (such as a lack of land security for women); and iii) policies and laws to guide planning and implementation in ways that avoid or minimise inequality, discrimination or injustice. Accounting for these can offer opportunities for broader local buy-in, enhancing the legitimacy of LDN efforts and tackling socio-cultural norms that hinder women and men from working together in land management/restoration/rehabilitation initiatives (Broeckhoven and Cliquet, 2015). 
Agarwal, B. 2001. Participatory exclusions, community forestry, and gender: an analysis for South Asia and a conceptual framework. World Development 29:1623-1648.

Agarwal, B. 2010. Gender and green governance: the political economy of women's presence within and beyond community forestry. Ecological Economics 68(11): 2785-2799.

Aguilar, L. 2014. Introducing on gender and restoration: a case study series. Retrieved online from https://www.iucn.org/content/introducing-gender-and-restoration-case-studyseries (Accessed 21/03/2018).

BRIDGE 2011. Gender and climate change overview report. Institute of Development Studies, Brighton, United Kingdom.

Broeckhoven, N., Cliquet, A. 2015. Gender and ecological restoration: Time to connect the dots. Restoration Ecology 23(6):729-736.

Chhatre, A., Lakhanpal, S., Larson, A., Nelson, F., Ojha, H., Rao, J. 2012. Social safeguards and co-benefits in REDD+: A review of the adjacent possible. Current Opinion in Environmental Sustainability 4: 654-660.

den Besten, J. 2011. Women in REDD+. In Aguilar L, Quesada-Aguilar, A and Shaw DMP, eds. Forests and Gender. Gland, Switzerland: International Union for Conservation of Nature and New York, NY: Women's Environment and Development Organization.

Doss, C., Kovarik, C., Peterman, A., Quisumbing, A., van den Bold, M. 2015. Gender inequalities in ownership and control of land in Africa: myth and reality. Agricultural Economics 46: 403-434. Doi: 10.1111/agec.12171.

Doss, C., Meinzen-Dicka, R., Quisumbinga, A., Theis, S. 2018. Women in agriculture: Four myths. Global Food Security 16: 69-74. Doi: 10.1016/j.gfs.2017.10.001.

Doss, C., Summerfield, G., Tsikata, D. 2014. Land, gender and food security. Feminist Economics 20 (1): 1-23. DOI: 10.1080/13545701.2014.895021.

FAO 2009. Bridging the gap: FAO's Programme for Gender Equality in Agriculture and Rural Development. Rome, Italy: FAO.

FAO 2011 The State of Food and Agriculture - Women in Agriculture: Closing the Gender Gap for Development, 2010-2011, p.3.

FAO 2018. Why is gender equality and rural women's empowerment central to the work of FAO? Retrieved online from http://www.fao.org/gender/background/en/ (Accessed 14/06/2018).

GBM 2018. The Green Belt Movement. Online at http://www.greenbeltmovement.org (Accessed 2/03/2018).

Hirao, K. 2016. Environment and gender. The Wiley Blackwell Encyclopaedia of Gender and Sexuality Studies. Doi: 10.1002/9781118663219.wbegss706.

IPBES Report, 2018. Summary for policymakers of the thematic assessment report on land degradation and restoration of the Intergovernmental Science-Policy Platform on Biodiversity and Ecosystem Services. R. Scholes, L. Montanarella, A. Brainich, N. Barger, B. ten Brink, M. Cantele, B. Erasmus, J. Fisher, T. Gardner, T. G. Holland, F. Kohler, J. S. Kotiaho, G. 
Von Maltitz, G. Nangendo, R. Pandit, J. Parrotta, M. D. Potts, S. Prince, M. Sankaran and L. Willemen (eds.). IPBES secretariat, Bonn, Germany. 32 pages.

Jackson, C. 2003. Gender analysis of land: beyond land rights for women? J. Agrar. Chang. 3 (4): 453-480. Doi: 10.1111/1471-0366.00062.

Johnson, N., Kovarik, C., Meinzen-Dick, R., Njuki, J., Quisumbing, A. 2016. Gender, assets and agricultural development: lessons from eight projects. World Development 83: 295-311. Doi: 10.1016/j.worlddev.2016.01.009.

Kissinger, G., Herold, M., De Sy, V. 2012. Drivers of deforestation and forest degradation: A synthesis report for REDD+ policymakers. Lexeme Consulting, Vancouver Canada.

Landesa 2015. Land rights, climate change and environmental stewardship - infographics. Retrieved online from https://www.landesa.org/resources/climate-change/ (Accessed 13/06/2018).

Larson, A., Dokken, T., Duchelle, A., Atmadja, S., Resosudarmo, I., Cronkleton, P., Selaya, G. 2015. The role of women in early REDD+ implementation: Lessons for future engagement. International Forestry Review 17(1):43-65.

Meinzen-Dick, R., Quisumbing, A., Doss, C., Theis, S. 2017. Women's land rights as a pathway to poverty reduction: Framework and review of available evidence. Agricultural Systems. Doi: 10.1016/j.agsy.2017.10.009.

Nelson, V., Forsythe, L., Morton, J. 2015. Empowering dryland women: capturing opportunities in land rights, governance and resilience. A synthesis of thematic papers from the series 'Women's empowerment in the drylands'. 12pp. Natural Resources Institute, University of Greenwich, Chatham, UK.

Nightingale A. 2002. Participating or just sitting in? The dynamics of gender and caste in community forestry. Journal of Forest and Livelihoods 2:17-24.

Orr, B. J, Cowie, A. L, Castillo Sanchez, V. M, Chasek, P., Crossman, N. D, Erlewein, A., Louwagie, G., Maron, M., Metternicht, G.I, Minelli, S., Tengberg, A. E., Walter, S., Welton, S. 2017. Scientific conceptual framework for land degradation neutrality. A Report of the Science-Policy Interface. United Nations Convention to Combat Desertification (UNCCD), Bonn, Germany.

Pham, T. 2016. Gender mainstreaming in REDD+ and PES. Lessons learned from Vietnam. Info-brief. Bogor, Indonesia: Center for International Forestry Research.

Quisumbing, A., Kumar N. 2014. Climate-smart agricultural practices in rural Ethiopia. The gender-differentiated impact of land rights knowledge. Climate Change, Collective Action, \& Women's Assets. Washington, DC: International Food Policy Research Institute.

Ramsay, D. 2017. COP23 Special: Recognizing Gender Bias, Restoring Forests, Forests News. Bogor, Indonesia: Center for International Forestry Research. https://forestsnews.cifor .org/52685/ cop23-special-recognizing-gender-bias-restoring- forests?fnl=en (Accessed 17/03/2018).

Rao, N. 2017. Assets, agency and legitimacy: Toward a relational understanding of gender equality policy and practice. World Development 95:43-54. 
Samandari, A. 2017. Towards gender-Sensitive Land degradation neutrality. UNCCD draft Working Paper for the global Land Outlook, paper p2.

UN Women 2018. Towards a gender-responsive implementation of the united nations convention to combat. Retrieved online from http://www.unwomen.org//media/headquarters/attachments/sections/library/publications/2018/towards-a-genderresponsive-implementation-of-un-convention-to-combat-desertification en.pdf?la=en\&vs=3803 (Accessed 21/03/2018).

UNCCD News, 2017. LDN Fund officially launched. Retrieved online from https://www.unccd .int/news-events/Idn-fund-officially-launched (Accessed 21/06/2018).

UNCCD, 2017. Turning the tide: the gender factor in achieving land degradation neutrality. Retrieved online from https://www.unccd.int/sites/default/files/documents/2017_Gender_ END.pdf (Accessed 12/03/2018).

UNEP, 2012. Powerful synergies: gender equality, economic development and environmental sustainability. Retrieved online from http://www.undp.org/content/undp/en/ home/librarypage/womens-empowerment/powerful-synergies.html (Accessed 20/04/2018).

UNCCD, 2016. Land Degradation Neutrality: The Target Setting Programme. Retrieved online from http://www.unccd.int/Lists/SiteDocumentLibrary/Publications/4_2016_LDN_ TS\%20_ENG.pdf (Accessed 24/04/2018).

Verma, R. 2001. Gender, Land, and Livelihoods in East Africa: Through Farmers' Eyes. International Development Research Centre, ON, Canada, p. 280.

Villamor, G., van Noordwijk, M., Djanibekov, U., Chiong-Javier, M., Catacutan. 2014. Gender differences in land-use decisions: shaping multifunctional landscapes? Current Opinion in Environmental Sustainability 6(1): 128-133. Doi: 10.1016/j.cosust.2013.11.015.

WFO 2013. Rural women in the world. World Farmers Organisation e-letter. Retrieved from http://www.wfo-oma.org/media/k2/attachments/WFO_Farmletter_10_2013_1.pdf (Accessed 07/06/2018).

B. Supplementary Materials

Table S1. LDN-related projects selected (2012-2018)

LDN-related projects and the gender issues/dimensions included

1. Promoting Sustainable Land Management (SLM) through Integrated Restoration of Ecosystems - Albania [Objective: Strengthening capacity and skills of national and local government institutions and promoting sustainable land management practices in Albania through integrated ecosystem restoration]

Source: https://www.thegef.org/sites/default/files/project_documents/4-19-16_-PIF_and_PPG_doc -0.pdf

Duration: 36 months duration from 2017

The project includes participation of a women group - the Kolonja Women's Association - to take the lead in developing the baseline gender analysis. Local farmers and farmer associations (including women and men) are incorporated to participate in project design and planning, including 
participation in validation workshops. Gender issues captured include: the challenges faced by women in terms of their vulnerability to the impacts of soil degradation; and gender-balanced support in terms of training for both men and women to adopt SLM practices. Stakeholder consultations, meetings, workshops and trainings considered gender balance and the representation of various ethnic and religious groups. Project pushes for: equal participation of women and men in relevant ecosystem restoration and land use planning activities; awareness raising activities to highlight the importance of inclusion of all representative groups; and baseline gender analysis during preparation phase. Project promotes women's participation on project activities by establishing quotas linked to training activities via collaborations with the Kolonja Women's Association on gender matters. Gender equality is planned through wider 'gendered' participation in decision-making and implementation of SLM programs.

Project is characterised mostly by 'gendered participation'. Issues on land rights, tenure security and differential workloads are not captured; also cost and benefit sharing for women and men is not articulated - there is an absence of validation measures/gender sensitive indicators to ensure equal access and benefits.

2. Restoring ecological corridors in Western Chad for multiple land and forests benefits RECONNECT - Chad [Objective: To improve the sustainable management of natural resources, and forest resources in particular, in order to reduce $\mathrm{CO}_{2}$ emissions and maintain ecosystem services]

Source: https://www.thegef.org/sites/default/files/project_documents/ID9417_GEF-6_PIF-MFAFSP-IUCN-Chad-Restoring_ecological_corridors_in_Western_Chad_to_mitigate_climate_change__RECONNECT_v2_1.pdf

Duration: 36 months from March 2018

Gender analysis is part of the project preparation phase, covering women's roles in natural resource management; whether women's activities are carried out individually or collectively; the level of structuring and organisation of collective activities; and the influence of women in collective decisionmaking in villages. Gender equality is pursued by systematically involving women's groups and vulnerable populations in defining project challenges - project activities are defined by accounting for the social and cultural characteristics peculiar to the project intervention area, whilst bearing in mind the need to involve men and women equally. Project recognises that women are at the very heart of natural resources management and are highly involved in harvesting timber and non-timber forest products, making them an important target group. The gaps here are in agreement with those related to project 1 above.

3. Sustainable Land Management in the Commonwealth of Dominica - Dominican Republic [Objective: An integrated land management model that includes agricultural, forestry and natural resources management practices that generate development and critical environmental benefits in tandem in the Commonwealth of Dominica]

Source:https://www.thegef.org/sites/default/files/project_documents/ID9667_Sustainable_Land_Ma nagement_Dominica_PIF_14.02.2017_clean_1.pdf

Duration: 36 months from April 2018

Dominica's Gender Policy is the main framework for gender mainstreaming in all project areas, aimed to drive gender awareness, incorporate a gender perspective in all development planning, policy formulation and implementation; and to facilitate achievement of environmental benefits for all. The project's gender equality drive was informed by the country's National Policy and Action Plan for Gender Equity and Equality; and draws on the country's successes in gender equity and equality as evident in the strides towards the social economic achievement of women. The project targets reducing violence against women and economic challenges through poverty reduction schemes for women and men. The Dominica National Council of Women (DNCW) is a key stakeholder involved in providing the technical support to assist in gender mainstreaming into the project activities.

The project has plans for: gender inequality assessment; gender-based monitoring and assessment, including development of socioeconomic indicators that are gender-specific. It incorporates understandings of ecosystem benefits for women. Knowledge management activities within the project are gender-responsive, aiming to integrate gender dimensions into publications, presenting 
sex-disaggregated data and gender sensitive language in publications and photos as a way to avoid presenting stereotypes; as well as ensuring that women, men and the youth have access to and benefit from the knowledge created.

4. Piloting Innovative Investments for Sustainable Landscapes - Brazil, Indonesia and Liberia [Objective: To maintain or increase forest cover, intensify agricultural production, and improve the livelihoods of smallholders through piloting de-risking finance for investments in sustainable landscapes in seven target landscapes in Brazil, Indonesia and Liberia]

Source: https://www.thegef.org/sites/default/files/project_documents/01-1317_MSP_Request_Docu ment_resubmission_clean.pdf

Duration: 36 months from February 2018

This project is concerned about forest protection as well as financial dynamics to support forest protection. It engages women and men in initial project discussion/design stage; pursues a balanced engagement between male and female landowners and land-workers; and emphasises that convening platforms (with local government, private sector, CSOs) should have representatives from women. The project considers impacts of project implementation on gender equality; highlights supports for men and women taking into account the social context on the ground; endorses collaborative management methods as an approach to engage stakeholders and account for gender issues in the design and implementation of project activities. It plans to use gender-sensitive indicators and sex-disaggregated data in project monitoring and evaluation plans.

5. Generating economic and environmental benefits from sustainable land management for vulnerable rural communities of Georgia - Georgia [Objective: To develop and strengthen sustainable land management (SLM) practices and build capacity at municipal scale for their application for the protection of natural capital in Georgia]

Source: https://www.thegef.org/sites/default/files/project_documents/Request_MSP_Approval.pdf

Duration: 36 months from January 2018

Project seeks to develop and strengthen sustainable land management practices - recognises women's role in agriculture and their low yield challenges due to limited resources (i.e. a lack of funds to purchase fertiliser, better seeds and other inputs), including facing greater risk of falling into extreme poverty. It is underpinned by a gender analysis covering development and implementation stages - and prioritises making contributions directly and indirectly to improve conditions of women, enhancing their capacity to participate in decision-making processes, and to engage in land use activities that have the potential to improve their economic situation. Through their participation, women are expected to benefit from skills development (education/training) and improved access to modern technologies and knowledge on land management, increasing both their incomes and social capital. The project plans to ensure that consultations among stakeholder groups, capacity-building programs and outreach programs all include an analysis of gender dimensions in order to maximise the participation of and the potential positive impacts for women. A specific budget is planned for gender sensitive project activities during project preparation phase, including gender-sensitive indicators and sex-disaggregated data for monitoring and evaluation plans.

6. Sustainable Land and Water Management - Ghana [Objectives: (a) demonstrate improved sustainable land and water management practices aimed at reducing land degradation and enhancing maintenance of biodiversity in selected micro-watersheds, and (b) strengthen spatial planning for identification of linked watershed investments in the Northern Savannah region of Ghana]

Source: https://www.thegef.org/sites/default/files/project_documents/03-2316_PID_ISDS_Appraisal .pdf

Duration: 36 months from May 2016

This project's approach to mainstream gender consideration is consistent with the GEF Policy on Gender Mainstreaming and the World Bank Group's renewed Gender strategy - both emphasise greater involvement of women in planning and decision-making structures and implementation. 
Indicator on direct project beneficiaries is disaggregated to capture the percentage of women out of all direct project beneficiaries.

7. Sustainable rangeland management for biodiversity conservation and climate change mitigation - Jordan and Egypt [Objective: To strengthen restoration and sustainable management of pastoral rangelands for the provision of ecosystem services and protection of biodiversity in Egypt and Jordan and catalysing scale up Regionally and globally]

Source: https://www.thegef.org/sites/default/files/project_documents/04-07-16_PIF_PPG_request_ document_2_0.pdf

Duration: 48 months from November 2017

Key stakeholders in the project are women rangelands users - they are central to project delivery and to the development of scale-up initiatives and policy dialogue. The project emphasises strengthening effective participation of women in rangelands management and in influencing public decision making. It integrates gender into relevant activities, collaborating with the Ministries in charge of gender. Planning exercises are disaggregated into men and women's groups, enabling women to be more vocal. Knowledge is sought into how women's view on resource management differ from men. Gender specific indicators and targets are developed to monitor progress on gender mainstreaming into rangeland governance. Community Environmental Management Planning is a central component of the project approach, providing an important entry point for strengthening the voice of women. Training provided aim to empower female participants to engage fully - trainers are required to have the skills and experience necessary to plan and facilitate gender-sensitive activities. Further, the project addresses women's weak access to resources and to government services by tackling vulnerability and low adaptive capacity to degradation; it also supports women's groups to developed more diverse livelihood activities through improved transformation and marketing of rangeland produce (livestock and non-livestock). Overall, the project highlights women's evolving rights as decision makers over rangeland resources within common property regimes and seeks to advance women's roles as herd managers, accommodating this in the development of innovative financing mechanisms for scaling up good practices.

8. Land degradation neutrality of mountain landscapes in Lebanon - Lebanon [Objective: To achieve land degradation neutrality of mountain landscapes in Lebanon through integrated landscape management]

Source: https://www.thegef.org/sites/default/files/project_documents/2-11-2016_PIF_UNDP_ID_58 37.pdf

Duration: 72 months from May 2018

The project accounts for the differences, needs, roles and priorities of men and women acknowledging that women are often the most vulnerable to land degradation; and that women can play active role in fostering land rehabilitation, restoration and sustainability. It aims to realise gender equality and women's empowerment by mainstreaming gender issues into project activities, ensuring that women have a real voice in project formulation, as well as governance and an active role in implementation. Women are expected to participate equally with men in any dialogue or decisionmaking initiated by the project and will influence decisions that will determine the success of the project and ultimately the future of their families.

9. Sustainable Forest Management and Conservation Project in central and southern Benin Benin [Objective: To promote socially and environmentally sustainable forest management in central and south Benin by improving forest and land management to preserve forest cover, prevent biodiversity loss, and monitor carbon stocks and emissions]

Source: https://www.thegef.org/sites/default/files/project_documents/ID9383 2016_07_07 _AfDB_Benin_PIF_clean_ADA.pdf

Duration: 48 months from May 2017

Project activities aim to empower women by pursuing several outcomes such as to: reduce the time and labour intensiveness of women's household chores by ensuring the availability of harvested forest resources in close proximity to households; increase capacity for training and educating 
women on activities related to sustainable forest management and conservation; increase overall health of beneficiaries using healthcare centres and other social infrastructure (schools, primary care centres, roads and paths) built under the baseline investment. Through forest management activities, the project plans to generate alternative incomes for women (e.g. from the production and sale of processed forestry products such as shea butter, fruits, and vegetables) which will subsequently improve their standards of living.

10. Scaling up a multiple benefits approach to enhance resilience in agro- and forest landscapes of Mali's Sahel regions - Mali [Objective: To enhance food security and multiple environmental benefits through sustainable, resilient and healthy agro- and forest ecosystems in the Sahelian regions of Mali based on a landscape approach]

Source: https://www.thegef.org/sites/default/files/project_documents/ID9293_GEF-6_PIF_Mali_ 13_07_2016_SFM_revised_24_08_2016_0.pdf

Duration: 60 months from May 2017

The project focuses on rural activities in which women have a recognised know-how (vegetable gardening, rice, small livestock, poultry, processing activities, etc.) and from which they can most benefit. It accounts for various gender dimensions - strong participation of women and youth; application of gender-sensitive infrastructure and technologies; enhancement of income-generating activities for women via enhanced agricultural productivity; and the strengthening of capacities of women associations. Training provided targets women's skills development in business planning, literacy, marketing techniques and financial management to strengthen entrepreneurship and empowerment at the local level. Other gender promoting activities planned include: producing gender-disaggregated data throughout the project's life cycle; analysing land tenure and raising awareness for enhanced women participation in production and income-generating activities; capacity building for women; strengthening the position of women's groups in agricultural and forestry product processing; facilitating women's access to factors of production; promoting gender-sensitive infrastructure to reduce women's burden; ensuring men and women have equal access to information, capacity building and awareness campaigns; facilitating gender sensitive budgeting and planning; hiring a gender expert for the Project Management Unit; and ensuring female participation in various decision making bodies.

11. Integrated Watershed Management for improved agro-pastoral livelihoods in the Sepabala sub-catchment - Lesotho [Objective: To mainstream sustainable rangeland management and restoration into the use of watersheds to combat land degradation, enhance the flow of agroecosystem goods and services and improve the livelihoods of agro-pastoral communities in the Sepabala Watershed in the Lower Senqu Basin]

Source: https://www.thegef.org/sites/default/files/project_documents/03-12-18_PIF_Request_ Document_revised.pdf

Duration: 48 months from June 2018

The project aims to use the UNDP and GEF guidance on mainstreaming gender into project design and implementation, carrying out a gender analysis/assessment from the outset to ensure that project design and implementation fully take into consideration the gender dynamics of natural resources governance. The Results Framework is intended to have clear gender-disaggregated indicators and targets, ensuring that monitoring and assessment plans, and budget, include activities and items that contribute directly to the implementation of gender action plan. Project outcome targets conditions where women, youth and poor men are better empowered with knowledge, tools, and skills gained through training and capacity building, as well as direct women's participation in interventions on the ground - women are expected to later adopt skills gained to benefit themselves as individuals and as community members.

12. Sustainable and Integrated landscape Management of the Western Area Peninsula - Sierra Leone [Objective: To strengthen the sustainable and integrated management of the protected area landscape in the Western Area Peninsula Landscape to protect globally significant biodiversity and safeguard streams of ecosystem services generating local and national socio-economic benefits]

Source: https://www.thegef.org/sites/default/files/project_documents/PIF_SierraLeone_171027 Revised_0.pdf 
Participatory approach is planned to guarantee inclusion of all relevant social groups - e.g. marginalised people with attention to the participation and inclusion of women. Gender considerations formed part of the project formulation process, and benefit sharing is planned to acknowledge and reward different contributions of women and men to sustainable management of natural resources. Gender mainstreaming is planned, e.g. through budgetary provisions focused on empowering women and girls through education, participation in decision-making, and access to equal justice and economic opportunities.

13. Sustainable Land Management for Increased Productivity in Armenia - Armenia [Objective: Increase incomes and assets generated by smallholder farmers through investments in sustainable land management systems and technologies]

Source: https://www.thegef.org/sites/default/files/project_documents/1-7-15__PIF_DOc.pdf

Duration: 72 months from November 2015

The project considers vulnerable women-headed households and youth, organising training and investment-support interventions suited for their specific needs. Specifically, it provides preferential access to entrepreneurship for women household heads and youth; and access to finance and markets. It also seeks for close liaison with selected partners (the Asian Development Bank with its relevant operations in women's entrepreneurship and SME development) to better reach out to vulnerable groups, to coordinate activities and provide support for women-oriented interventions.

14. Sustainable forest and landscape management project - Bosnia and Herzegovina [Objective: To build capacity of forestry sector stakeholders and to demonstrate approaches for sustainable forest and land management through integrated management of vulnerable forest, scrub and pasture landscapes]

Source:http://projects.worldbank.org/P129961/?lang=en\&tab=documents\&subTab=projectDocume nts

Duration: May 2014 - May 2019

The project's inclusion of participatory processes in forest and land management gives preference to communities close to forests, and provides equal opportunity irrespective of gender, giving community members the required opportunity to participate. Local extension services and community-based organisations are incorporated to facilitate local participation and capacity building activities. Gender data to be collected aim to inform how forestry planning and sustainable management initiatives affect men and women and their communities. Public awareness raising activities are planned to include women and men - capturing their different needs and opinions about priorities in management planning and implementation procedures. Overall, the project plans to enable equal access opportunities to men and women.

15. Using SLM to improve the integrity of the Makgadikgadi ecosystem and to secure the livelihoods of rangeland dependent communities - Botswana [Objective: To mainstream SLM in rangeland areas of the Makgadikgadi Sub-region productive landscapes for improved livelihoods of rangeland dependent communities]

Source: https://www.thegef.org/project/using-slm-improve- integrity-makgadikgadi-ecosystem-andsecure-livelihoods-rangeland

Duration: 48 months from May 2014

A gender analysis undertaken across the project cycle underpins development and implementation of alternative livelihoods to ensure women and other disadvantaged groups have access to and control of land resources. The analysis aims to provide disaggregated data for monitoring, in line with the UNDP gender marker, and for promoting a more effective targeting of initiatives to benefit women particularly those at high risk of suffering from the effects of rangeland degradation and climate change vulnerabilities. Project outcomes are expected to directly and indirectly contribute towards improving the condition of women - through enhancing their capacity to participate in decision making and engage in land use activities that increase the flow of benefits to improve their economic situation. The project plans to actively empower women and other excluded groups through social 
mobilisation and skills development, including providing them access to financial resources and markets for produced/harvested veld products utilising Women's Self-Help Groups and other such community-based structures.

16. Collaborative Management for Watershed and Ecosystem Service Protection and Rehabilitation in the Cardamom Mountains, Upper Prek Thnot River Basin - Cambodia [Objective: To restore and maintain forest cover and watershed stability functions while providing for sustainable livelihoods and ecosystem services in the Upper Prek Thnot Watershed]

Source: https://www.thegef.org/sites/default/files/project_documents/4-912\%2520\%250 Rev\%2520 PIF\%2520doc_0.pdf

Duration: 36 months from July 2014

The project aims to directly benefit women living in and depending on the forest ecosystem. Provision of land use rights will directly support acquisition of livelihood assets for women. It addresses gender empowerment by narrowing gender disparities through access to economic and financial resources and opportunities (i.e. security of land tenure, off-farm employment opportunities) and enhancing voices and rights (i.e. with representation in project decision-making bodies). The project provides women in target communities with inputs, guidance, and infrastructure that will enable increased productivity and incomes; reduce work burdens; and improve access to educational, health and social services. Preferential opportunities are offered households headed by women. Socioeconomic benefits and gender analysis are planned.

17. Enhancing Agro-ecological Systems in Northern Prefectures of the Central African Republic - Central African Republic [Objective: To ensure ecosystem protection, services and food security through enhanced agro-sylvo-pastoralism and sustainable natural resources management in CAR's Ouham and Ouham-Pendé prefectures]

Source:https://www.thegef.org/sites/default/files/project_documents/ID9532_GEF5_CEO_Endorse ment_CAR_revised_12_10_2016.pdf

Duration: 60 months from November 2016

The project recognises that women have a heavier workload compared to men, and have lower access to education, information, agricultural extension services, inputs and credit; including recognising that considerable land-related gender disparities exist, e.g. where fisheries activities are dominated by men but processing the catch falls on women. The project targets almost 8 million women as beneficiaries of program activities - e.g. by facilitating women's access to land security, productive resources ( $40 \%$ of land allocated to women's groups through local conventions) and planning capacity building activities (e.g. technical vocational and social training - including training reproductive health). The project also plans to foster women's participation in decision-making processes and investment; and to enhance the organisational capacity of women's producer groups so they can play a strategic role in promoting inclusive growth and improve their conditions in the project's target areas. It aims to put in place a gender-sensitive early warning system and a set of pro-women services centred on the development of alternative livelihoods and provision of technologies to reduce women's work time, increasing their productivity. It also aims to set up a monitoring and assessment system based on gender disaggregated data as well as on genderrelated indicators to capture the number of women working in investment and demonstration activities and those participating in trainings to be monitored. Project also highlights strengthening genderrelated stakeholders by recruiting a gender and socio-economic development specialist in the Regional Coordination Unit to enhance training and mainstreaming aspects.

18. Sustainable Land Management - Chile [Objective: To develop a national framework for sustainable land management to combat land degradation, mainstream biodiversity into national policies, and protect forest carbon assets]

Source:https://www.thegef.org/sites/default/files/project_documents/MFA\%25204104\%2520Chile\% 2520PIF_1.pdf

Duration: Project ended (July 2012-April 2018)

Gender issues are not highlighted. 
19. Community-based Sustainable Dryland Forest Management - Gambia [Objective: To improve community-based management of dryland forests in Gambia to reduce forest degradation and improve local livelihoods]

Source: https://www.thegef.org/sites/default/files/project_documents/08-13-13_PIF_Document_ revised_0.pdf

Duration: 60 months from May 2016

This project involves the Agency for the Development of Women and Children to enable improvement of the role of women entrepreneurs in forest products and enterprises through Self-help Groups; it improves the role of women in harvesting and processing techniques and value-addition of forest products.

20. Sustainable Forest and Land Management Project - Kyrgyzstan [Objective: To strengthen the institutional capacity for sustainable forest ecosystem management]

Source: https://www.thegef.org/sites/default/files/project_documents/4-7-15_-_PCN_doc_0.pdf

Duration: 84 months from July 2016

No gender issues are consideration in this project.

21. Participatory Sustainable Land Management in the Grassland Plateaus of Western Madagascar - Madagascar [Objective: To reverse land degradation and improve living conditions in the Bongolava Region of Western Madagascar through participatory sustainable management of the grasslands]

Source: https://www.thegef.org/sites/default/files/Project/documents/ID5354_Madagascar-GEF5_LD_MSP_CEO_Endorsement_Request_revised_05.09.2016_Clean_0.pdf

Duration: 48 months from September 2016

The project's land management plans have clear consideration of gender. Agro-ecological techniques emphasise land rehabilitation approaches that improve incomes for women. Participatory and inclusive management systems help communities to coordinate and maintain ecological balance and mitigate drought; special attention is given to women participation and women-led livelihood options. Women currently comprise about $43 \%$ of participants and more than $60 \%$ of institutional representatives, indicating that the project strongly incorporates women's views and interests. The project highlights division of labour between men and women in irrigated agricultural and other production system - i.e. men prepare the land, whereas women sow, harvest, and process crops. This way the project integrates men and women equally - it also provides gender-specific training and community cohesion.

22. Mainstreaming biodiversity into the management of the coastal zone in the Republic of Mauritius - Mauritius [Objective: To mainstream the conservation and sustainable use of biodiversity and ecosystem services into coastal zone management and into the operations and policies of the tourism and physical development sectors in the Republic of Mauritius through a 'landand seascape wide' integrated management approach based on the Environmental Sensitive Areas' (ESAs) inventory and assessment]

Source: https://www.thegef.org/project/mainstreaming-biodiversity-management-coastal-zone-rep ublic-mauritius

Duration: 48 months from March 2016

This project adopts the Human Rights-Based Approach to address gender bias. Project's participatory approach to management is gender-sensitive and socially-inclusive, focusing both on women and men as agents in promoting alternative sustainable livelihoods. It plans to assess, design, monitor and track implementation using a gender lens, distinguishing women and men as beneficiaries. It plans to develop gender-responsive monitoring indicators to ensure that: women's participation in project activities is not hampered by unpaid care work; alternative care arrangements are considered as part of development of sustainable and alternative livelihoods; women's 
participation does not worsen their unpaid work load; and that the project does not take advantage of gender biases in income to offer women benefits that are lower compared to men. The project aims to hire international and local gender experts to provide necessary expertise for implementation of the project goals.

23. Land Degradation Offset and Mitigation in Western Mongolia - Mongolia [Objective: To reduce negative impacts of mining on rangelands in the western mountain and steppe region by incorporating mitigation hierarchy and offset for land degradation into the landscape level planning and management]

Source:https://www.thegef.org/sites/default/files/project_documents/3-11-15_-_CEO_Endorse ment_Doc1_0.pdf

Duration: 48 months from April 2015

Project acknowledges the existence of a customary gender division of labour in the nomadic pastoral society in Mongolia: men are primarily responsible for herding animals, hunting, slaughtering animals, maintaining animal shelters, repairing carts, tools, and weapons; whereas women are mainly responsible for housework, milking animals, making dairy products, cooking, washing, sewing, and nurturing children. Project draws from a broad-based consultative process, including women at all levels. Focused group discussions capture gender issues; also sensitisation workshops and awareness-raising programs are designed to ensure that at least $50 \%$ of the target participants are women. Activities geared towards mobilising local communities into organised groups encourage women to participate, aiming to have at least one women functionary in each local coordination committee.

24. Sustainable management of Namibia's forested land - Namibia [Objective: To reduce pressure on forest resources by facilitating policy \& capacity enabling environment for the uptake of improved practices in agriculture, livestock and forestry management in the community forest areas]

Source: https://www.thegef.org/sites/default/files/project_documents/12-13-13_CEO_Endorsement _Request_Final_0.pdf

Duration: 72 months from December 2013

This project adopts the UNDP and GEF gender policies and strategies, giving special attention to gender equity and ensuring participation of women in livelihood enhancement activities and in the landscape management planning processes. The role of women in conservation and development is enhanced through the provision of training, access to resources and forums for women's participation - the inclusion of women in economic activities is expected to boost local economies, household incomes and wealth creation.

25. Strengthening the National Protected Areas System of Swaziland - Swaziland [Objective: To strengthen management effectiveness of Swaziland PAs to respond to existing \& emerging threats to biodiversity]

Source: https://www.thegef.org/sites/default/files/project_documents/09-10-12\%2520PIF\%2520 document\%2520revised_0.pdf

Duration: 72 months from July 2014

Project aims to increase benefits from tourism for women stakeholders through increased participation. As women are an important stakeholder in food production and household economics, the project plans to conduct a gender analysis during the design stage to identify the ways in which gender relations affect, or are affected by access to, control and use of natural resources, and how these relationships are likely to influence project outcomes and sustainability. Findings are expected to be used to formulate a gender strategy to guide project implementation, to ensure that project targeting promotes effectiveness of implementation, fair and equitable access to and distribution of project benefits.

26. Integrated community-based forest and catchment management through an ecosystem service approach - Thailand [Objective: To create an enabling policy and institutional environment to scale-up integrated community-based forest and catchment management practice] 
Source: https://info.undp.org/docs/pdc/Documents/THA/78499_4033_Thailand_Community_

Based_Prodoc_August_\%202011\%20(signed).pdf

Duration: $2012-2017$

This project acknowledges women as primary users and managers of land, forest, water and other natural resources, playing a leading role in community-based environmental advocacy and natural resource management. It highlights that gender sensitivity and equity would play an important role in project success. Project promotes the participation of women and supports women in leadership and decision-making capacities - active participation in decision-making and the equitable sharing of benefits between men and women is crucial for ensuring the long-term sustainability of natural resource management. Special attention is given to equitable participation of women and men in decision making as well as in benefit distribution.

27. Promoting Sustainable Land Management (SLM) Through Strengthening Legal and Institutional Framework, Capacity Building and Restoration of Most Vulnerable Mountain Landscapes - Macedonia [Objective: To develop and strengthen national policy and institutional capacity for sustainable land management (SLM) and to contribute to achieving the national land degradation neutrality target with integrated landscape management in north-western mountainous ecosystems of Macedonia]

Source: https://www.thegef.org/sites/default/files/project_documents/3-27-17_SLM_LD_Macedonia _PIF_revised_-cleanv_0.pdf

Duration: 48 months - concept approved November 2017

Project adopts the UN Environment's commitment to gender equality and women's empowerment by accounting for the differences, needs, roles and priorities of men and women. It acknowledges that women are often the most vulnerable to land degradation such as that resulting from poor management of agricultural and forestry sector. Project plans to mainstream gender equality and women's empowerment into project activities, ensuring that women have an equal voice in project implementation, as well as governance and an active role during the whole project. It highlights that women will participate equally with men in any initiated dialogue or decision-making and will influence decisions that will determine the success of the project and ultimately the future of their families. Gender analysis (from the outset) aims to identify more specifically the areas for women's participation at the outcome level - budget is allocated during the planning phase for mainstreaming gender equality during the project.

28. Strengthening Management Effectiveness and Generating Multiple Environmental Benefits within and around Protected Areas in Zambia - Zambia [Objective: To ensure that the biodiversity and carbon sinks of Zambia - particularly those critical forest landscapes in selected protected areas (including core National Parks and buffer Game Management Areas) - are better protected from threats through improved management effectiveness at the institutional level; sustainable forestry management practices and integrated land use planning at the local level; and application of appropriate low-carbon, biomass-energy technologies]

Source: https://www.thegef.org/project/strengthening-management-effectiveness-and-generatingmultiple-environmental-benefits-within

Duration: 60 months from October 2013

Project aims to improved income streams for charcoal workers - although charcoal production process is done mostly by men, women are integrated at different stages in production, transportation and sale, upscaling their capacity to sell large quantities of charcoal to end-users at market points in urban centres. It highlights that the management and development of energy resources at the grassroot level requires effective participation of women and men in decision making. Women play a vital role in the provision and management of energy resources in rural areas and are required to take proactive decisions on how energy resources are managed and developed.

29. Comprehensive and integrated management of natural resources in Borno State - Nigeria [Objective: To maintain the provision of ecosystem services in Nigeria's Borno state by preserving agro- and forest ecosystems in a context of improved production, conservation and renewable energy to secure multiple environmental and socioeconomic benefits] 
Source: https://www.thegef.org/project/lcb-nree-nigeria-child-project-comprehensive-and-integra ted-management-natural-resources

Duration: 60 months from December 2016

Gender issues are not visible in the text, result framework, the indicators, and the monitoring and evaluation document.

30. Improving Sustainable Management of Natural Resources in Niger's Diffa Region - Niger Republic [Objective: To enhance agro-sylvo-pastoralism and landscape productivity in Niger's Diffa region by rehabilitating agro and forest ecosystems in support of food security and environmental protection]

Source: https://www.thegef.org/project/lcb-nree-niger-child-project-improving-sustainable-manage ment-natural-resources-niger\%E2\%80\%99s

Duration: 60 months from December 2016

This project acknowledges that women represent about $52 \%$ of the population in the area and have a heavier workload compared to men, including having lower access to education, information, agricultural extension services, inputs and credit. The project aims to reduce gender disparities by facilitating women participation in decision-making and investment, access to land security and by enhancing the organisational capacity of women's producer groups, improving their situation as a result. It highlights women's integration and ownership as a core objective to be realised through setting up a gender-sensitive early warning system and promoting basin resource users' forums comprising a set of pro-women services centred on the development of alternative livelihoods and suitable technical vocational and social trainings (including in reproductive health). Project aims to set up a M\&E system based on gender disaggregated data as well as on gender-related indicators number of women working in investment and demonstrations activities and those participating in the trainings will be monitored. Project plan involve stakeholders, and gender and socio-economic development specialist in the Regional Coordination Unit to enhance training and gender mainstreaming.

Table S2. Questions that guided reading and assessment of projects.

Reading and assessments of projects are guided by the following questions:

- What are the specific gender elements/issues integrated in the project preparation/plan?

- In what ways are the differences, needs, roles, and priorities of women and men presented, integrated and/or addressed?

- Does the project emphasis how and why gender matters for land management/ restoration?

- Is the project explicit about approaches to address gender bias and support female empowerment?

- In what ways are gender issues/concerns different across countries and what general principles/norms can be promoted; and what opportunities exist to maximise gender and women's expertise to achieve gender-responsive LDN? 
Table S3. A logical framework to follow-up on the status of gender equality in LDN-related national initiatives

\begin{tabular}{|c|c|c|c|}
\hline Intervention logic & $\begin{array}{l}\text { Gender-sensitive } \\
\text { indicator }\end{array}$ & Verification & Assumption \\
\hline $\begin{array}{l}\text { A gender-responsive } \\
\text { approach to be } \\
\text { mainstreamed } \\
\text { across sectors and } \\
\text { subordinate } \\
\text { authorities }\end{array}$ & $\begin{array}{l}\text { Gender-responsive } \\
\text { actions that contribute } \\
\text { to LDN are included in } \\
\text { a national } \\
\text { development vision }\end{array}$ & $\begin{array}{l}\text { Regular national reports } \\
\text { on the implementation } \\
\text { of LDN and other } \\
\text { international goals } \\
\text { include a section on the } \\
\text { status and trends in } \\
\text { gender-responsive } \\
\text { actions }\end{array}$ & $\begin{array}{l}\text { Policy provides an } \\
\text { enabling environment to } \\
\text { implement LDN which } \\
\text { considers gender } \\
\text { equality as a basic } \\
\text { human right }\end{array}$ \\
\hline $\begin{array}{l}\text { Policies and } \\
\text { procedures on land } \\
\text { ensure equal } \\
\text { treatment of women } \\
\text { and men }\end{array}$ & $\begin{array}{l}\text { Secured equal rights } \\
\text { for women and men } \\
\text { before law }\end{array}$ & $\begin{array}{l}\text { The rights of women to } \\
\text { access and to control } \\
\text { land resources are } \\
\text { enabled and secured, } \\
\text { leading to gender } \\
\text { equality in land use } \\
\text { rights and land } \\
\text { ownership }\end{array}$ & $\begin{array}{l}\text { National institutions are } \\
\text { in place that regulate } \\
\text { equal access to and } \\
\text { control over land } \\
\text { resources }\end{array}$ \\
\hline $\begin{array}{l}\text { Women and men } \\
\text { understand the } \\
\text { concept of LDN and } \\
\text { have access to } \\
\text { knowledge/best } \\
\text { practices on } \\
\text { measures to } \\
\text { avoid/reduce/reverse } \\
\text { land degradation }\end{array}$ & $\begin{array}{l}\text { Capacity-building / } \\
\text { training on } \\
\text { understanding LDN } \\
\text { concept and locally } \\
\text { adapted guidelines } \\
\text { which include female } \\
\text { and male local } \\
\text { knowledge about } \\
\text { environmental as well } \\
\text { as decision-support } \\
\text { tools are provided and } \\
\text { used by men and } \\
\text { women }\end{array}$ & $\begin{array}{l}\text { The awareness of LDN } \\
\text { and means to } \\
\text { implement it rises } \\
\text { equally among male } \\
\text { and female farmers }\end{array}$ & $\begin{array}{l}\text { Female and male } \\
\text { farmers are responsive } \\
\text { to the implementation of } \\
\text { SLM }\end{array}$ \\
\hline $\begin{array}{l}\text { Female and male } \\
\text { farmers implement } \\
\text { measures to } \\
\text { avoid/reduce and } \\
\text { reverse land } \\
\text { degradation to slow } \\
\text { down or halts the } \\
\text { loss of productive } \\
\text { lands }\end{array}$ & $\begin{array}{l}\text { Female and male } \\
\text { farmers use SLM } \\
\text { technologies }\end{array}$ & $\begin{array}{l}\text { National monitoring } \\
\text { shows a rise in land } \\
\text { areas where SLM is } \\
\text { applied accompanied } \\
\text { by a decline in the net } \\
\text { loss of productive lands }\end{array}$ & $\begin{array}{l}\text { Incentives and a secure } \\
\text { policy and regulatory } \\
\text { environment give } \\
\text { female and male } \\
\text { farmers the security for } \\
\text { long-term investments } \\
\text { in enhancing and } \\
\text { maintain the } \\
\text { productivity of their } \\
\text { lands }\end{array}$ \\
\hline
\end{tabular}


